\title{
Lusioersily
}

\section{Construction and evolution of submerged deltaic bodies on the high energy SE African coastline: The interplay between relative sea level and antecedent controls}

Engelbrecht, L., Green, A., Cooper, A., Hahn, A., Zabel, M., \& McKay, CF. (2020). Construction and evolution of submerged deltaic bodies on the high energy SE African coastline: The interplay between relative sea level and antecedent controls. Marine Geology, 424, [106170]. https://doi.org/10.1016/j.margeo.2020.106170

Link to publication record in Ulster University Research Portal

\section{Published in:}

Marine Geology

Publication Status:

Published (in print/issue): 01/06/2020

DOI:

10.1016/j.margeo.2020.106170

\section{Document Version}

Author Accepted version

\section{General rights}

Copyright for the publications made accessible via Ulster University's Research Portal is retained by the author(s) and / or other copyright owners and it is a condition of accessing these publications that users recognise and abide by the legal requirements associated with these rights.

\section{Take down policy}

The Research Portal is Ulster University's institutional repository that provides access to Ulster's research outputs. Every effort has been made to ensure that content in the Research Portal does not infringe any person's rights, or applicable UK laws. If you discover content in the Research Portal that you believe breaches copyright or violates any law, please contact pure-support@ulster.ac.uk. 
Construction and evolution of submerged deltaic bodies on the high energy SE African coastline: The interplay between relative sea level and antecedent controls

\section{A B S TR A C T}

This paper investigates the interplay between allocyclic controls and antecedent topography in the evolution of submerged coastal landforms, including a back-stepped delta. Using high-resolution tools, we examine the wave-dominated Thukela shelf, and define the major seismic units. Key features identified comprise incised valleys scoured into bedrock, that have overspilled to form lagoons at depths of $50 \mathrm{~m}$. These are in turn overlain by two prograding and backstepped sandy delta systems at $40 \mathrm{~m}$ and $32 \mathrm{~m}$ depth respectively. The deltas interfinger with muddy prodelta deposits and are truncated by the Holocene ravinement, overlain by the contemporary prodelta of the Thukela River system. A bedrock high separates two physically separate strato-morphological zones; landward a sediment stripped, steep and shallow nearshore zone, and seaward a gentle zone downdip where the deltaic accumulations are sited. Delta development was favoured during sea-level stillstands at $-40 \mathrm{~m}$ and $-32 \mathrm{~m}$ respectively. The step-back of the deltas corresponds to sharp increases in the rate of sea-level rise associated with meltwater pulses. The overall gentle palaeobathymetric gradient has moderated erosion associated with rising sea level, preserving a sandy back-stepping delta and a draping mud clinoform.

Submerged delta positioning relates to underlying incised valleys, suggesting a synchronous transgressive evolution of the drainage and the delta. Incised valley network positioning is further governed by Late Pliocene aged growth faults in the basement rocks. The geological framework has acted as a recurring primary control to the geomorphic evolution of the area, partitioning accommodation for sediment accumulation and moderating the efficiency of ravinement.

\section{Introduction}

Many of the lowest-lying and most densely populated coastal areas in the world occur on deltas. Their vulnerability to rising sea levels, subsidence and catchment alteration is well documented (e.g., Milliman et al., 1989; Ericson et al., 2006; Syvitski and Saito, 2007; Syvitski et al., 2009; Vörösmarty et al., 2009; Milliman and Farnsworth, 2011; Yang et al., 2011; Dai et al., 2014; Dai et al., 2016; Wei et al., 2017; Wang et al., 2017; Besset et al., 2019). Understanding how deltas respond to changing sea level and sediment supply is a key societal need. Analysis of historical change on deltas is useful in this regard, but additional evidence of delta morphologic and sedimentary response to a wide range of rates of pre-historic sea-level change can be deduced from submerged deltas.

Submerged deltas are often preserved offshore as relict sedimentary deposits on the shelf. These deposits provide windows into how contemporary 
delta systems may respond to contemporary and future rates

of sea-level change. Topset rollovers mark palaeo-shorelines, and multiple

offlap breaks assist in describing changing shoreline trajectories

and coastal configurations over time. This sheds light on the main

drivers of coastal change for the delta (e.g. sea level, sediment supply

etc.). In the context of Late Pleistocene to Holocene sea-level change,

this is serendipitous given that these periods have experienced sea-level

rises of magnitudes equal to or greater than those currently predicted to

occur over the next century by the International Panel of Climate

Change (IPCC, 2019). A glimpse into the past may thus provide a "worst

case scenario" for the future of the delta.

Submerged deltas have been documented offshore many of the largest river systems in the world (e.g.

Nittrouer et al., 1986; Alexander

et al., 1991; Kuehl et al., 1997; Chen et al., 2000), and, together with

increasingly tide-dominated settings such as the East China Sea

(Butenko et al., 1985; Dai et al., 2014), reflect a diverse literature on

delta behaviour in the offshore environment. However, few examples

exist of submerged deltas from wave-dominated coastlines. In most

cases, transgression from the Last Glacial Maximum (LGM) has all but

removed the delta form, resulting in the development of thick shoreface

successions that reflect strong wave-dominance (cf. Hernández-Molina

et al., 2000). Some notable exceptions include the Ombrone (Di Bella

et al., 2014) and Tagliamento (Zecchin et al., 2015) Rivers of the

Mediterranean, the Orange River of southern Namibia (Kirkpatrick

et al., 2019) and submerged deltas of the NE Gulf of Mexico (Gardner

et al., 2007).

Given the wave-dominance of these settings, the preservation of these features is mostly related to sharp rises in the rates of relative sea level rise, prompting the in-place drowning of the delta forms. Little attention has been given to the role of antecedent geology on the evolutionary pathway of these systems.

Kirkpatrick and Green (2018) and Kirkpatrick et al. (2019) were amongst the first authors to recognise the degree geological framework may control relict wave-dominated delta form and evolution, especially in the context of high rates of sediment supply. It is from this perspective that we examine the Thukela River delta offshore the east coast of South Africa. The Thukela River is the 4th largest river to enter the SW Indian Ocean (after the Limpopo, Zambezi and Save). It debouches onto a moderately wide and shallow bedrock-framed shelf. Seaward of the modern delta, the shelf comprises a variegated and unusual mix of 
seafloor facies ascribed to auto and allocyclic processes (Green and Mackay, 2016). These include long-standing energetic wave regimes, punctuated rises in Holocene sea level, and the influence of a strong boundary current on sediment dispersal. The aim in this paper is to describe and interpret the stratigraphy of submerged deltaic deposits in the context of postglacial delta evolution up to the present, focussing in particular on the role of bedrock control on delta form over time.

2. Regional setting

The Thukela shelf forms part of the KwaZulu-Natal bight, an area of broadened shelf situated between Durban and Richards Bay, on the east coast of South Africa. When compared to the global averages for shelf gradient $\left(0.12^{\circ}\right)$ and width $(73 \mathrm{~km})$ (Shepard, 1963), most of the KwaZulu-Natal shelf is characterised by a considerably steeper and narrower shelf $\left(0.24^{\circ}\right.$ and $18 \mathrm{~km}$ off Durban) (Goodlad, 1986; Green et al., 2013a). However, offshore the Thukela River, the shelf flattens and broadens to $0.13^{\circ}$ and $\sim 45 \mathrm{~km}$ respectively (Goodlad, 1986; Martin and Flemming, 1986), with a shallow shelf break located at $\sim 100 \mathrm{~m}$ water depth (Green et al., 2013a).

The coastline of the study area (Fig. 1) is wave-dominated, with average significant wave heights offshore Durban and Richards Bay of $1.8 \mathrm{~m}$ and $1.5 \mathrm{~m}$, respectively. Swells mostly approach from the southeast (Salzmann et al., 2013). The Thukela shelf and adjacent coast is microtidal (SAN, 2014), with a spring tidal range of $1.8 \mathrm{~m}$ (Moes and Rossouw, 2008). The shelf edge is dominated by the poleward-flowing Agulhas Current, with equatorward counter-current flows occurring inshore (Schumann, 1988). These flows are compounded in the littoral by a vigorous northward-directed longshore current (Orme, 1973; Green and Mackay, 2016). The contemporary delta comprises two parts: a subaqueous/wave-dominated delta (Bosman et al., 2007) and an onshore component comprising a downdrift, prograding beach ridge plain (Green et al., 2013c).

Entrainment of sediment from the northward directed longshore drift $(1.0 \times 106 \mathrm{~m} 3 \cdot y \mathrm{r}-1)$ is one of two major allochthonous sediment inputs to the Thukela shelf, second only to fluvial input $(6.79 \times 106$ $\mathrm{m} 3 \cdot \mathrm{yr}-1$ ) from the Thukela River (the largest river on the KwaZuluNatal coastline) (Mcormick et al., 1992; Bosman et al., 2007). The subordinate autochthonous sediment input is via biogenic production $(<5 \%)$, where shelf sediments reflect a seaward-increasing calcium carbonate content (Fleming and Hay, 1988).

The Thukela shelf comprises the uppermost part of the Thukela 
Cone, a deep-water fan complex of late Cretaceous to Tertiary age (Hicks and Green, 2016). The shelf break is marked by the offlap break of a Pliocene-aged normal-regressive lowstand shelf edge wedge (Hicks and Green, 2016) into which valleys have incised during sea-level lowstands (Martin and Flemming, 1988; Green et al., 2013b). These valleys are filled and the interfluves overlain by thin sediment veneers that thicken landwards into the contemporary muddy and sandy subaqueous delta deposits (Green and MacKay, 2016). Transgression from the Last Glacial Maximum (LGM) 18,000 yr BP has resulted in the distribution of patchy gravels and muds along the shelf edge and outer shelf, comprising relict bioclasts and older lagoonal deposits, each exposed by post-glacial transgressive erosion (Green and MacKay, 2016). Overall sea-level rise after the LGM (Ramsay and Cooper, 2002), involves a series of marked stillstands associated with development and preservation of shoreline features (Green et al., 2014) with intervening periods of rapid rise (Fig. 2), up to the present which was reached about $7 \mathrm{kyr}$ cal BP (Cooper et al., 2018a). A subsequent highstand of + ca. $2 \mathrm{~m}$ was reached ca $5 \mathrm{kyr}$ cal BP before sea level fell to the present (Cooper et al., 2018a).

3. Materials and Methods

High-resolution single-channel seismic reflection data were collected using a $200 \mathrm{~J}$ Applied Acoustics boomer system, coupled to an 18-element hydrophone array. Positioning was achieved using a differential global positioning system (DGPS), with position fixes acquired at $1 \mathrm{~s}$ intervals. Data were collected and processed using the Hypack ${ }^{\mathrm{TM}}$ software, with time-varied gain, bandpass filter (300 to $1200 \mathrm{~Hz}$ ), swell filtering and manual seabed tracking applied. Streamer layback and antenna offset corrections were applied to all digitized data, and constant sound velocities in water $(1500 \mathrm{~m} / \mathrm{s})$ and sediment $(1600 \mathrm{~m} / \mathrm{s})$ were used to extrapolate all time-depth conversions. All data resolve to approximately $70 \mathrm{~cm}$ in the vertical domain.

High-resolution seismic profiles were collected using a PARASOUND parametric echosounder aboard the RV Meteor, during cruise M123. The low frequency output $(3.5 \mathrm{kHz})$ was selected due to signal attenuation of the higher-frequency spectra. The data were de-spiked and match-filtered, and the data exported in SEGY format for visualization in Hypack ${ }^{\mathrm{TM}}$. The vertical resolution of these data is approximately $10 \mathrm{~cm}$.

A 7,17 m-long gravity core (GeoB20621-1) was retrieved from a depth of $\sim 34 \mathrm{~m}$ below mean sea level, directly offshore of the Thukela 
River mouth during RV Meteor cruise M123 (29¹5.981'S;

$\left.31^{\circ} 33.490^{\prime} \mathrm{E}\right)$. The core allowed for the examination of the sub-surface stratigraphy of the study area and ground-truthing of the seismic results.

The core was split into archive and working halves, scanned immediately after opening using a smartcube $\odot$ camera image scanner capturing high resolution digital photographs, and logged according to standard sedimentological procedures. A single box core was also retrieved for ground truthing of the upper $1 \mathrm{~m}$ sediment package of the submerged delta $\left(29^{\circ} 15.965^{\prime} 31^{\circ} 33.525^{\prime}\right)$.

The gravity core was sub-sampled for AMS C14 dating (Table 1), microfossils and grain size analyses. The AMS $\mathrm{C} 14$ dates were calibrated using OXCAL software (Ramsey, 2001) and the marine13.14c calibration model (Reimer et al., 2013).

4. Results

4.1. Seismic stratigraphy

Nine seismic units were resolved on the Thukela continental shelf, identified on the basis of seismic impedance, reflection termination patterns, internal-reflection configuration and bounding acoustic reflectors

(Table 2).

\subsubsection{Unit 1}

Unit 1 comprises the acoustic basement of this study. It is characterised by continuous, sigmoid prograding, gently seaward dipping high amplitude reflectors (Figs. 4-10). It is at least $30 \mathrm{~m}$ thick, but the basal surface lies below the penetration capability of seismic system, or is obscured by the multiple in shallower water. The upper bounding surface of Unit 1 is easily distinguished as a high amplitude surface I (SB1), truncating underlying reflectors. In areas where the overlying units are absent, SB1 has been subsequently reworked by an additional phase of erosional truncation (SB2) (Figs. 3 and 4). These surfaces exhibit a clear discordant relationship between the underlying Unit 1 and the overlying material (Figs. 5 and 6).

\subsubsection{Unit 2}

Overlying SB1, Unit 2 comprises two distinct seismic facies (Fig. 3).

Unit 2.1 appears as pinnacles that may occur as acoustically opaque, or chaotic, very high amplitude reflector sets. The overall undulating nature of the unit results in considerable variation in thickness up to a maximum of $15 \mathrm{~m}$. Unit 2.2 onlaps the seaward side of Unit 2.1 (Fig. 3) and comprises a series of flat-lying to inclined, low amplitude to nearly transparent reflectors that downlap SB1. Unit 2.2 has a maximum thickness of $2 \mathrm{~m}$. Both Unit 2.1 and 2.2 are erosionally truncated by the 
high continuity, high amplitude erosional SB2 (Fig. 7).

\subsubsection{Unit 3}

Unit 3 occurs only proximally and is not observed on the middle to outer shelf. It occurs landward of the subjacent Unit 2 (Fig. 3) and is separated from the underlying Unit 1 by SB1, which it onlaps and downlaps. Unit 3 is acoustically transparent and is incised by several of the valleys formed in SB2. Due to its association with the sporadically occurring Unit 2, the lateral extent of Unit 3 is limited, observed exclusively landward of Unit 2. Unit 3 can reach thicknesses of up to $3 \mathrm{~m}$ and is erosionally truncated by SB2. SB2 forms a laterally extensive, channelled cross-shelf surface (Fig. 10a).

The SB2 incisions vary greatly in their width, depth and overall distribution (see description of Unit 4). The position of the incisions is associated with a series of faults in the underlying basement strata (Figs. 3, 6).

These valleys are more prominent south of the contemporary Thukela river, and a clear sinuous channel pattern is evident (Fig. 10a). The SB2 surface is generally flat $\left(0.1^{\circ}\right.$ to $\left.0.3^{\circ}\right)$, with localised maxima associated with the valley walls (Fig. 10b). A prominent coast-parallel gradient knickpoint $\left(0.6^{\circ}\right)$ is evident north of the contemporary river mouth (Fig. 10b).

\subsubsection{Unit 4}

Unit 4 comprises two sub-Units. Unit 4.1 forms the incised valley fill material that has accumulated in the deep incisions of SB2 (Figs. 3 and 6 ). Due to the highly irregular nature of the valley incisions, the lateral extent, thickness and overall internal reflector configuration of each valley fill succession varies considerably (Fig. 10b). The widths may vary from tens of metres to kilometres (Figs. 6 and 7), with thicknesses that range from $10 \mathrm{~m}$ to $40 \mathrm{~m}$ (Figs. 3 and 7 ).

The internal reflectors range from acoustically transparent through high amplitude reflectors, and may comprise wavy, sigmoidal to highly irregular reflector geometries. These generally onlap the incised valley walls. The upper bounding surface truncates the incised valley fill material.

Unit 4.2 is restricted to valley incisions and their immediate interfluves, overspilling the valleys. Unit 4.2 mostly overlies Unit 4.1, capping the valley fill material, or where Unit 4.1 is absent, overlies Units 1 and 3 . Unit 4.2 is located throughout the study area, from the inner to the outer shelf, maintaining an overall consistent thickness of approximately $2-4 \mathrm{~m}$, comprising sub-parallel to wavy, moderate to 
high amplitude reflectors, onlapping SB2 or where pinnacles of Unit 2.1 occur. The uppermost portions of Unit 4.2 are erosionally truncated by a high amplitude reflector ii.

\subsubsection{Unit 5}

Characterised by low to moderate amplitude, continuous parallel to subparallel reflectors, Unit 5 drapes SB2 (Figs. 4 and 8), or when an incised valley is present, overlies Unit 4.2 (Fig. 3). Additionally, Unit 5 abuts pinnacles of Unit 2.1 (Fig. 5). Unit 5 occurs as a uniformly $4-5$ mthick, flat lying unit, and apart from the extreme proximal regions of the shelf, extends over most of the continental shelf where its uppermost reflector forms a flat, featureless surface (Fig. 10c).

\subsubsection{Unit 6}

Unit 6 comprises a variety of internal reflectors, which range from acoustically transparent to high amplitude reflectors (Figs. 3 and 6).

The internal geometry is complex, with bimodally orientated prograding reflector sets that dip both landward and seaward (Figs. 8 and 9), together with contorted reflectors (Fig. 9). Localised concave down reflectors are also observed in the most seaward portions of the seismic profiles (Fig. 3), together with occasional mounded forms (Fig. 4). Small-scale channels $<5 \mathrm{~m}$ wide and up to $2 \mathrm{~m}$ deep are common, separating sub-sets of the progradational facies (Fig. 9). The deposit thickness varies considerably; its overall geometry comprises a seaward thinning wedge with discrete aggradational lobes up to $15 \mathrm{~m}$ thick. Unit 6 is truncated by a continuous high amplitude surface (iii). Fig. 10d highlights the well-developed lobate form of Unit 6, 10 km north of the contemporary river mouth. The topset break of the unit (abrupt change in depth) forms an arcuate, northward-widening form with the landward position dictated by the inflection point formed in SB2 (Fig. 10b and d).

\subsubsection{Unit 7}

Unit 7 is an isolated unit that forms a wedge between the underlying Unit 6 and the overlying Unit 8. It is limited in its occurrence (Figs. 5 and 7). The unit comprises low amplitude, continuous sigmoidal reflectors that onlap surface III (Fig. 7), as well as pinnacles of Unit 2.1 (Fig. 5). The reflectors dip to both the NE and SW. Unit 7 is approximately $6 \mathrm{~m}$-thick, where material is draped between highpoints of the adjacent Units 2.1 and 6. Like Unit 6, the upper bounding surface of Unit 7 is a continuous high amplitude reflector, surface IV (Fig. 5).

\subsubsection{Unit 8}

Unit 8 displays a broadly similar seismic expression to that of Unit 6, forming a seaward prograding wedge (Figs. 3 and 6). Bimodally orientated 
sigmoid reflectors are apparent, dipping landward and seaward where they downlap surfaces III and IV (Figs. 8 and 9). Unit 8

attains a maximum thickness of $12 \mathrm{~m}$.

Like Unit 6, this unit forms a lobate shape in the subsurface

(Fig. 10e) with two high points, a minor one to the south of the study area, and a prominent lobe where the topset break, is seaward of the Unit 6 lobe. Where Units 6 and 8 are at their thickest (the topset break point), a matching positive relief in the sea floor is observed (Figs. 6 , $8-10 h)$.

Units 8 and 6 are erosionally truncated by the high amplitude regional reflector $\mathrm{v}$. This surface forms a uniformly seaward dipping erosional surface that steepens and shallows abruptly immediately landward of the topset break of Unit 8. A second and more pronounced steepening occurs in association with the underlying gradient knickpoint of SB2 (Figs. 5, 10b).

\subsubsection{Unit 9}

The uppermost and youngest unit of the study, Unit 9 comprises low amplitude, continuous parallel reflectors that drape and onlap the underlying units (Figs. 5 and 8). The upper portions of Unit 9 form the modern-day seafloor of the study area, with a maximum thickness of $10 \mathrm{~m}$. The main depocenter is immediately seaward of the bedrock knickpoint (Fig. 10g) where the thickest accumulations are observed, beyond which the unit thins progressively seawards and drapes Units 6 , 7 and 8 . Unit 9 drapes the underlying surface $v$.

The contemporary seafloor bathymetry mirrors strongly the upper surfaces of both Unit 6 and Unit 8 (Fig. 10d and f). The same positive relief feature is repeated in the seafloor as is currently observed (Fig. 10h), with a strong component of down-drift asymmetry.

\subsection{Lithostratigraphy}

GeoB20621-1 comprises a basal coarse shell hash with a sandy matrix that is overlain by a series of alternating light and dark clay laminae (Fig. 11a). Isolated mud clasts are found above the basal coarse shell hash, which are in turn overlain by isolated shell debris within a clay matrix. This comprises the main unit of the core, a strongly laminated clay with occasional sand lenses (Fig. 11b). The uppermost $30 \mathrm{~cm}$ of the core comprises bioturbated clays overlain by a $5 \mathrm{~cm}$-thick sand layer marking the modern sea floor. The upper $7 \mathrm{~m}$-thick package of laminated clays corresponds to Unit 9 (Fig. 11c). The shell hash at the base corresponds to the wave ravinement surface (wRS), which separates Unit 8 from Unit 9. A box 
core targeting Unit 8 reveals this unit to comprise medium quartzose sand with shell fragments. Where wRS crops out seaward, grab samples described by Green and MacKay (2016) reveal it to comprise a shell hash similar to that of the basal unit of the core.

AMS C14 ages from the laminated clay unit range from 432 to 1866 cal yr BP (Table 1). Despite several age reversals, the overall trend of the AMS data points to a late Holocene age of deposition for Unit 9.

5. Discussion

\subsection{Seismic interpretation}

\subsubsection{Pre-LGM deposits}

Unit 1 represents the lowermost resolvable unit in the study area, occurring as a continuous across shelf progradational to aggradational unit. Hicks and Green (2016) identified this as a normal-regressive lowstand shelf edge delta of Pliocene age. Green (2011) described a similar, albeit thinner sediment package from $\sim 100 \mathrm{~km}$ north, which was considered the final phase of shelf-edge wedge aggradation in the late Pliocene (Green et al., 2008). Unit 1 is locally truncated by SB1. Unit 2 comprises 2 distinct seismic facies that occur in association with each other (Unit 2.1 and Unit 2.2), and which overlie the SB1 surface (the oldest resolvable subaerial unconformity in the study area). The pinnacle-like morphology and seismic signature of Unit 2.1 is identical to the aeolianite pinnacles described from both seismic (Green et al., 2013c; Green et al., 2018) and multibeam bathymetry (Green et al., 2014) for the adjoining shelf regions, and from other tropical temperate shelves worldwide (Shtienberg et al., 2016; Brooke et al., 2017). These features are equivalent to modern coastal dunes and barrier successions that have been lithified, with their preservation linked to rapid drowning (Pretorius et al., 2016; Cooper and Green, 2016).

Unit 2.2 is likely to have been deposited subsequent to the formation and lithification of the aeolianite, based on its seaward onlapping relationship with Unit 2.1. Green et al. (2018) and Cooper et al. (2019) recognised similar acoustic facies which they ascribed to debris liberated by aeolianite breakdown that later forms a residual deposit along the seaward fringe of the palaeo-shoreline. The timing of deposition is uncertain.

Unit 3 is observed exclusively on the landward side of the barrier complexes of Unit 2.1. Similar deposits were documented onlapping the landward sides of aeolianites on the Durban shelf (Green et al., 2013c). Their specific location, together with their acoustic transparency, suggests 
deposition of fine sediment in a sheltered back-barrier type environment.

Coring of similar acoustic facies behind submerged barrier

successions revealed these deposits to comprise back barrier and estuarine material of $35,395 \pm 592 \mathrm{yr}$ B.P. (Pretorius et al., 2016),

which correlates with the age of similar lagoonal material (Green and MacKay, 2016) found seaward by Fleming and Hay (1988). This alludes to the presence of an extensive ( 100 km along strike) series of lagoons formed during Marine Isotope Stage (MIS) 3 along this shelf.

5.1.2. LGM lowstand and subsequent incised valley/interfluve deposition The SB2 surface is marked by a number of incisions which can be correlated shelf-wide from the Eastern Cape (South Africa) to central Mozambique (De Lecea et al., 2017). Following Zecchin and Catuneanu (2013) we consider this surface and its associated incised valleys to be a subaerial unconformity. Given the stratigraphic position as the uppermost incised surface, together with its links to a regional network of incised valleys (Green et al., 2013a; Dladla et al., 2019; Pretorius et al., 2019), it is interpreted as the subaerial unconformity related to the LGM lowstand when sea levels fell to $\sim 130 \mathrm{~m}$ below present, $\sim 30 \mathrm{~m}$ below the contemporary shelf break (Green and Uken, 2005; Ramsay and Cooper, 2002; Cooper et al., 2018a).

Unit 4.1 comprises the ensuing Late Pleistocene to Holocene incised valley fills, deposited during the postglacial (MIS 1/2) transgression. The large incisions are the offshore expression of the modern-day Thukela river system. The consistent link between basement faulting and valley position is clear, and emphasizes the role of geological inheritance on incised valley development (cf. Menier et al., 2006; Bhatt and Shah, 2017). A tidal ravinement surface, with similar seismic expressions to that documented by Benallack et al. (2016), caps the incised valley fill material, formed as a result of migrating tidal inlets and channels during sea-level rise (Green et al., 2015).

Capping the incised valley fill successions and overspilling the adjoining interfluves, Unit 4.2 is very similar to the uppermost deposits of LGM-age incised valleys recognised on the Durban shelf by Green et al. (2013a), and on the coastal plain to the north of the study area by Benallack et al. (2016) and Dladla et al. (2019). These are revealed to be lagoonal materials that overtop the interfluves due to prolonged sea level stability and overfilling of the valley form (Green et al., 2013a). This unit is developed around a depth of $50 \mathrm{~m}$, which correlates well with those depth occurrences for this unit offshore Durban. Coring and dating of those deposits revealed an age of $11,573-11,357 \mathrm{cal} \mathrm{yr}$. BP 
(Pretorius et al., 2016), which is consistent with other evidence of a slow rise or stillstand of sea level at $\sim-50 \mathrm{~m}$ during the Younger Dryas (Cooper et al., 2018a).

\subsubsection{Transgressive sand sheet}

The flat-lying, uniform parallel geometry of Unit 5 is in keeping with transgressive sand sheets observed in seismic sequences elsewhere (e.g. Kirkpatrick et al., 2019), and this unit is interpreted as such. Owing to the broad, flat nature of the shelf, any increase in rates of sealevel rise would foster a rapid landward advancement of the shoreline, resulting in limited aggradation or stacking of thick transgressive deposits. Relict sands and thin transgressive sand deposits are most likely formed, distributed as laterally extensive, thin sand sheets (Liu et al., 2000; Berné et al., 2002).

This unit also occupies a comparable stratigraphic position to sheets elsewhere that underlie large-scale shelf clinoforms (such as those of Unit 6) (Liu et al., 2004; Zecchin et al., 2010). The more proximal nature of this deposit, when compared to the more seaward overspilled lagoonal deposits of Unit 4.2, points to an increase in the rate of sealevel rise after deposition of Unit 4.2.

\subsubsection{Delta deposition}

The stepped sigmoidal prograding seismic reflection configuration of Unit 6 closely resembles the constructional phase of a sandy delta (cf. Bhattacharya, 2006; Patruno et al., 2014; Patruno et al., 2015), prograding over the transgressive sandsheet deposits of Unit 5. This kind of delta geometry, in the form of steep foreset progradation over relatively flat-lying transgressive deposits, is common, see for example the Canterbury Basin, New Zealand (Carter et al., 1998) or the Shandong Clinoform, China (Liu et al., 2004). Although some clinoforms form during forced regressive conditions (Plint and Nummedal, 2000), most are formed through normal regression, associated with highstand, lowstand, or decreased rates of sea-level rise (slowstand) (e.g. Kirkpatrick et al., 2019). The sigmoidal geometry of this portion of the delta is common in clinoforms that form proximal to river mouths (Christie-Blick and Driscoll, 1995), implying active supply of sediments and a proximal sediment source. In some portions of Unit 6, some landward-dipping reflectors are present. These may indicate washoverfan deposition (e.g. Martínez-Carreño et al., 2017) or landward progradation of flood-tidal deltas (Patruno and Helland-Hansen, 2018). Additionally, a lateral component (apparent from shore parallel profiles) reveals a mounding geometry with bi-directional progradation 
on either side, which may be an example of delta lobe advancement, switching and abandonment. This occurs when significant proportions of river-derived sediment are reworked and recycled into new delta lobes (cf. Bhattacharya, 2013). The position of the topset/foreset break indicates that the shoreline was positioned approximately $8 \mathrm{~km}$ seaward of the modern coast, at approximately $40 \mathrm{~m}$ below present sea level as indicated by the consistent depth of clinoform rollover (Fig. 10d).

The draped, low amplitude nature of Unit 7 seismic reflectors are comparable to those observed in the muddy clinoforms of the Shandong prodelta (Liu et al., 2004) as well as those in the Yellow Sea muddy prodelta (Lee et al., 2016). Based on the similarities to other muddy prodelta geometries and seismic expressions, Unit 7 is interpreted as a muddy prodelta, now overlying the sandy delta foresets (Unit 6). This implies backstepping of the delta, whereby the relatively distal portions of the delta now directly overlie the delta front. The landward translation of the shoreline during a rapid rise in sea level, would foster such an overall landward translation of the depositional units.

Unit 8 is very similar to Unit 6 and shows continued downlap onto the upper surface of the previous delta form, together with progradation over the back-stepped muddy prodelta of Unit 7 . Unit 8 seems thus to comprise a second phase of delta construction during normal regression, whereby the topset of the delta caps the previous phase of delta outbuilding, with foreset progradation occurring past the basinward extremities of Unit 6 . This requires a further period of sea-level stability to produce a second normal regressive phase of delta outbuilding. As with Unit 6, the position of the topset/foreset break implies a delta shoreline at $\leq 35 \mathrm{~m}$ water depth, slightly seaward of the Unit 6 delta. Preservation of prodelta sediments seawards of each preceding delta phase is related to the complex interplay between sediment supply, waves and shelf currents, and accommodation space, controlled by magnitude and rate of relative sea level change (Liu et al., 2004; Aagaard et al., 2013). In the case of the submerged Thukela Delta, the sediment supply is abundant, as evidenced by the outbuilding of proximal delta facies. Reciprocity between wave energy and accommodation space is therefore suggested as the principal controlling factor in the distribution and preservation of Unit 7. The muddy prodelta deposits (Unit 7) are only preserved in areas of shelter in the saddle of the topset of the underlying Unit 6 (Figs. 6 and 8). This provides sufficient accommodation to preserve 
this small portion of the delta form from ravinement processes. It

shields otherwise easily reworked muddy sediment from wave action and complete reworking. Elsewhere, there is limited accommodation for such muddy deposits as the delta is transgressed. The short relaxation time for mud on such a high-energy shelf, explains the downdip absence of Unit 7, especially where flat-lying ravinement profiles indicate periods where transgressive erosion was concentrated (see Davis and Clifton, 1987; Pretorius et al., 2016).

GeoB 20621-1 (Fig. 11a) reveals the erosional surface overlying the deltaic units to comprise a coarse marine shell hash (cf. Cattaneo and Steel, 2003; Zecchin and Catuneanu, 2013). Dates from the overlying materials are all Holocene in age and we thus associate this surface with Holocene wave ravinement. The underlying deltaic units were partially reworked by wave action during the landward translation of the shoreline, however, this erosion was insufficient to completely overprint the delta form (see Fig. 10e and f).

Draping this surface is the contemporary mud clinoform of the Thukela River (the contemporary "muddy prodelta" as opposed to Unit 7's earlier phase of delta construction). This is an interbedded and interlayered succession of silt-clay-fine sand-organic matter (Fig. 11), similar to mud clinoforms observed elsewhere (Mediterranean Sea e.g. Gensous and Tesson, 2003, and the Yellow River subaqueous delta e.g. Liu et al., 2004; Hwang et al., 2014). In these examples, the absence of sandy material is usually related to trapping of coarser material proximally in mouth bars or tidal sand bodies (Leonardi et al., 2013). Seismic profiles from the Thukela clinoform clearly show that this is not the case. The nearshore is dominated by the cropping out of basement rocks, indicating that it is a zone of local sediment bypass or erosion. The dominant muddy deposition may thus be more likely related to lowered fluvial competencies during the contemporary highstand (Kirkpatrick et al., 2019) as opposed to proximal sediment partitioning.

\subsection{General discussion}

\subsubsection{Primary drivers of delta formation}

To explain the subaqueous delta geometry of the Thukela shelf, we consider the sea level (Fig. 2) and sediment supply constraints on the system. Two phases of normal regression have occurred and are responsible for the two-step lobe development.

The first relates to a shoreline occupation of $\sim 40 \mathrm{~m}$, the other to a shoreline occupation of $<35 \mathrm{~m}$. The second phase is more difficult to precisely ascertain since the delta topset has been modified in some 
places by seafloor erosion by ravinement. When compared to the local sea level history of SE Africa (Cooper et al., 2018a), the first phase of development potentially relates to a slowstand where sea-level rose from $-46 \mathrm{~m}$ to $-42 \mathrm{~m}$ between 11.5 and 10.6 cal kyr BP.

The second phase of delta building is tentatively linked to slowly rising sea levels from $-26 m$ to $-23 \mathrm{~m}$ over the period of 10.1 to $\leq 9$ cal kyr BP (Cooper et al., 2018a). During these periods, it was likely that accommodation creation was outpaced by a ready source of sediment supply. A similar period of sea-level stability post-dating MWP-1B but predating MWP-1C has been identified in the Yellow River subaqueous delta 11-9.2 ka BP, and at depths of $42 \mathrm{~m}$ to $38 \mathrm{~m}$ (Liu et al., 2004), corresponding to increased discharge and sediment loads, which they compared to contemporaneous increased discharge and sediment loads in other Asian rivers: Yangtze, G-B, Indus, Mekong (Chen et al., 2000; Goodbred and Kuehl, 2000; Prins and Postma, 2000; Ta et al., 2002). A later period of global delta formation was identified by Stanley and Warne (1994) 9-7 cal kyr BP.

In general, high rates of relative sea-level rise, coupled with the low gradient topography of the shelf, favour drowning and preservation of coastal landforms (Sanders and Kumar, 1975; Rampino and Sanders, 1980). This is often manifest in back-stepping, landward-directed shoreline trajectories (Törnqvist et al., 2004; Rodriguez et al., 2010). Implied step-back of the Thukela delta is consistent with a punctuated increase in the rate of sea-level rise, which we resolve to the period between $10.2 \mathrm{cal}$ kyr BP to $9.85 \mathrm{cal}$ kyr BP, when sea levels rose up to $16 \mathrm{~m}$ in 600 years (Cooper et al., 2018a).

Liu et al. (2004) describe a rapid sea-level rise at a similar time between 9.8 and $9 \mathrm{ka}$. This sea level rise from $36 \mathrm{~m}$ to $16 \mathrm{~m}$ in the space of approximately 800 years ( $45 \mathrm{~mm} /$ year) is termed MWP-1C. The later backstepping and preservation of delta phase 2 correlates best with the sharp rise in sea level associated with the $8.2 \mathrm{ka}$ event (Kendall et al., 2008).

Despite sea level being a prominent control on the preservation of the drowned delta form, sediment supply is also important. The Thukela river appears to have maintained sufficient sediment delivery to the shelf to construct an appreciable body of deltaic sediment. The total volume of material accumulated in the two delta phases is approximately $1.2 \AA \sim 108 \mathrm{~m} 3(1,7 \AA \sim 108 \mathrm{t}$ assuming a sediment density of 1500 kg.m-3) (Flemming and Hay, 1984). Applying a conservative time for accumulation from $11.5 \mathrm{kyr}$ to $9 \mathrm{kyr}$, the material accumulated 
at $7.18 \AA \sim 105 \mathrm{t} . y r-1$. This is an order of magnitude lower than the calculated modern rates of sediment yielded by the river

(5.6 $\AA \sim 106 \mathrm{m3} . y r-1$ ) (Flemming and Hay, 1984). Despite the high degree of preservation, significant losses of deltaic sediment over the cycle of delta deposition seem likely. This was likely due to northward dispersal in the longshore drift.

Given the energetic nature of the KwaZulu-Natal coast (Smith et al., 2010), it seems remarkable to preserve a body of soft sediment considering the erosive potential of the wave base as it translates up-profile during transgression, even if the rate of relative sea-level rise was rapid. An alternative explanation may be wave dampening by a muddy seafloor, however, the area is well-known for the large breaking waves that characterise it as a navigation hazard for shipping (see Flemming, 1978) and this seems a counterintuitive argument. In light of the high rates of sediment delivery to the area, we assume that sediment-surplus conditions for the shoreface (Mellett et al., 2012; Mellett and Plater, 2018) prevailed.

In these instances, the shoreface does not cannibalise itself as it migrates landward and sufficient sediment exists for portions of the shoreface to be preserved as relict features on the submerging sea floor. The constituent sandy nature of the sediment body promotes preservation as a function of increased inertia (Cooper et al., 2018b) and resilience to reworking which, coupled with the low gradient shelf that forms the basement of the delta, increases the propensity for overstepping during landward translation of the shoreface (Mellett and Plater, 2018).

Given the uniformly high abundance of sediment supply from infilled valleys (Cooper, 1993) our model suggests that deltaic outbuilding is favoured by sea-level stability. In this regard, the absence of delta deposits associated with the slowstand at $\sim 50 \mathrm{~m}$ to $45 \mathrm{~m}$ depth (Cooper et al., 2018a) is puzzling. In contrast to the delta forming, overspilled lagoonal facies of Unit 5 at this depth instead represent an intermediate stage of system evolution between unfilled accommodation in the incised valleys and the final bypass stage of deltaic outbuilding. Until a geomorphic threshold was reached whereby the incised valleys could be totally filled, topset-foreset delta construction could not develop along this portion of coast. This points to a topographic control that led to locally increased accommodation space at $-50 \mathrm{~m}$.

5.2.2. Antecedent controls on delta development and preservation 
This observation prompts consideration of the localised geological controls on delta development Submerged delta preservation and changing delta morphology. The landward extent of the mud clinoform is fixed by a gradient inflection in the basement slope. The submerged sandy delta onlaps this knickpoint, constraining the delta location seaward of this bedrock high. Seaward of the inflection point, the flatter bedrock profile provided more accommodation, as opposed to the nearshore platform that is elevated and within the wave base (Smith et al., 2010) (Fig. 10).

The landward limiting role of high bedrock relief and steep gradients means that only in the available accommodation seaward can a thick clinoform develop. This relationship between the sandy delta positioning and the bedrock palaeo-high points to a first order control on the delta geometry by the palaeo-bathymetry of the subaerial unconformity. Given the high-wave energy of the area, the palaeobathymetric gradient has further aided in the high degree of preservation of both mud clinoform and back-stepping deltas (e.g.

Kirkpatrick and Green, 2018).

The relatively flat surface has promoted a gentle shoreline trajectory, and has moderated the erosion associated with ravinement (Helland-Hansen and Gjelberg, 1994; Cattaneo and Steel, 2003). Landward, the steeper profile of the bedrock would increase ravinement efficiency due to the steep shoreline trajectory moving over a very narrow across-shelf width. This, coupled with a stepped rise in sea level, is likely to promote overstepping of this "accommodated" delta despite the aggressive wave climate. A similar scenario has been evoked for low-gradient-setting submerged shorelines by Green et al. (2018). When examining the wave ravinement morphology in comparison to the upper delta surface of Unit 8 (Fig. 10f), it is also evident that a strong influence has been exerted on the transgressive shoreline trajectory by the delta form. This is consistent with the implied losses from the delta during ravinement.

Nevertheless, the submerged delta morphology has overprinted successive phases of deposition by virtue of the seafloor maintaining a distinct shape that mimics the underlying delta forms (Fig. 10h). This implies that sediment supply and sea level rise are not the only controlling factors that govern the seafloor geomorphology of the shelf. The inheritance of the sandy delta shape, even within the context of the contemporary shoreface geomorphology is clear. Geological inheritance may thus play a far greater role than previously envisioned on high 
energy, high sediment supply coasts (as outlined in Kirkpatrick and Green, 2018).

The positioning of the delta is also related to the location of incised valleys (Fig. 6), where it occurs updrift of the modern Thukela River. This is typical of asymmetrical wave-dominated deltas in high sediment supply, high wave energy settings (e.g. Bhattacharya and Giosan, 2003). Its close association with incised valleys suggests synchronous transgressive evolution of the drainage system and the delta. Here it is important to note that faults in the basement rocks control the positioning of the incised valley network. These are likely Late Pliocene growth faults related to shelf outbuilding (Goodlad, 1986; Green, 2011).

\subsubsection{Evolutionary summary}

Postglacial evolution of the delta has led to the formation and preservation of four different coastal configurations associated with sea-level stillstands. These include a - $50 \mathrm{~m}$ non-delta (overspilled estuary), deltas at $-40 \mathrm{~m},-35 \mathrm{~m}$ and the contemporary delta. Their development is illustrated in Fig. 12 and their sequential development is discussed below.

The initial positioning of the incised valley network during the LGM and thus the main sediment delivery points were fixed by basement faults (Fig. 12a). The ensuing rise in sea level saw a series of shorelines develop as rising sea level flooded the shelf (cf. Green et al., 2014). During a sea-level stillstand/slowstand at ca $-50 \mathrm{~m}$, the valleys incised during the LGM retained a large accommodation space that prompted the formation of lagoons/estuaries, as opposed to a delta (Fig. 12b). Lagoonal deposits were preserved by subsequent rapid rise in sea level (MWP-1B). After successive stillstand/slowstands in sea level, sandy deltas were constructed at $-40 \mathrm{~m}$ and $-32 \mathrm{~m}$ (Fig. 12c and d, respectively). Their alongshore positions were governed by the location of the (now sufficiently filled) incised valley network, and their landward location by the seafloor knickpoint inherited from the underlying bedrock. Each of these deltas was preserved by overstepping, related to both low-gradient bedrock topography and episodic and rapid rises in sea level. Muddy prodelta facies were preserved between the successive delta lobes where sufficient accommodation space existed. A lack of accommodation space seaward of the $-40 \mathrm{~m}$ delta precluded preservation of prodelta sediments.

The contemporary delta comprises the typical asymmetric shape of a wave-dominated delta, with a series of downdrift prograding beach 
ridges. The nearshore is underlain by a bedrock high and lacks accommodation space. It is instead a zone of sediment bypass with muddy deposition further seaward (Fig. 12e). The onshore coarse fraction (beachridge plain) and fine seaward (mud clinoform) portions of the modern delta are consequently physically separated.

6. Conclusions

Seismic stratigraphic investigations offshore of the modern wavedominated Thukela delta reveal the presence of a variety of submerged coastal landforms, both deltaic and non-deltaic. Their form and preservation have been interpreted in the context of rates of sea-level change, sediment supply, and, importantly, antecedent topography. Topographic control is evident in terms of: fault-controlled fluvial outlet points; depth to bedrock; bedrock gradient; and previous delta morphology. These in turn influence accommodation space for sediment accumulation and the efficiency of ravinement.

Sea-level control is manifest in development of sediment accumulations during slow- or stillstands and in preservation during rapid rates of sea-level rise. These influences are, however, modulated by the topographic influences. Thus, a prolonged sea-level stillstand at $-50 \mathrm{~m}$ did not lead to delta progradation (because the underlying basement slope created a large accommodation space causing fluvial sediment to be sequestered in a lagoon/estuary), while perhaps shorter stillstands at $-40 \mathrm{~m}$ and $-32 \mathrm{~m}$ did favour delta development. Likewise, the modern delta consists of two physically separated components as a result of a topographic high in the nearshore zone.

Credit author statement

Engelbrecht: Writing - Original Draft, Conceptualization,

Green - Supervision, Writing - Review and Editing, Resources.

Cooper - Writing - Review and Editing.

Hahn - Resources, Funding Acquisition.

Zabel - Resources, Funding Acquisition.

Mackay - Resources, Validation.

Declaration of competing interest

The authors declare that they have no known competing financial interests or personal relationships that could have appeared to influence the work reported in this paper.

Acknowledgements

We acknowledge the captain and crew of the RV Meteor, cruise M123. We further acknowledge our colleagues on the cruise, Marc Humphries, Lauren Pretorius, Errol Wiles, Talicia Pillay, Hayley 
Cawthra, Nadia Du Plessis, Sergio Andò, and Peter Frenzel. Rev. Doug

Slogrove is thanked for his assistance in a second seismic survey campaign.

This project has been supported by the Bundesministerium für

Bildung und Forschung (BMBF; projects RAiN2 and MA-RAIN; Grant

No. 03G0862A and 03F0731A). LE acknowledges a scholarship from

the National Research Foundation/African Coelacanth Ecosystem

Programme (Grant No 97968). Finally, we thank the two anonymous

reviewers and the editor, Prof. E. Anthony, for their valuable inputs to

the paper.

References

Aagaard, T., Greenwood, B., Hughes, M., 2013. Sediment transport on dissipative, intermediate and reflective beaches. Earth Sci. Rev. 124, 32-50. https://doi.org/10.

1016/j.earscirev.2013.05.002.

Alexander, C., Demaster, D., Nittrouer, C., 1991. Sediment accumulation in a modern epicontinental-shelf setting. The Yellow Sea: Marine Geology 98, 51-72. https://doi. org/10.1016/0025-3227(91)90035-3.

Benallack, K., Green, A., Humphries, M., Cooper, J., Dladla, N., Finch, J., 2016. The stratigraphic evolution of a large back-barrier lagoon system with a non-migrating barrier. Mar. Geol. 379, 64-77. https://doi.org/10.1016/j.margeo.2016.05.001.

Berné, S., Vagner, P., Guichard, F., Lericolais, G., Liu, Z., Trentesaux, A., Yin, P., Yi, H.I., 2002. Pleistocene forced regressions and tidal sand ridges in the East China Sea. Mar.

Geol. 188, 293-315. https://doi.org/10.1016/s0025-3227(02)00446-2.

Besset, M., Anthony, E.J., Bouchette, F., 2019. Multi-decadal variations in delta shorelines and their relationship to river sediment supply: an assessment and review. Earth-

Science Reviews 219, 193-199.

Bhatt, N.H., Shah, R.D., 2017. Analysis of tectonically controlled valley floor morphology of the central segment of Sabarmati River basin: an integral approach using satellite images and GIS techniques. J Ind Geophys Union 21, 507-515.

Bhattacharya, J.P., 2006. Deltas. In: Posamentier, H., Walker, R.G. (Eds.), Facies Models Revisited: SEPM, Special Publication. v. 84. pp. 237-292.

Bhattacharya, J.P., 2013. Ancient Backwaters and Baylines: Slope Magnitude and its Control on Deltaic Facies Partitioning in Ancient Deltaic Systems.

Bhattacharya, J.P., Giosan, L., 2003. Wave-influenced deltas: geomorphological implications for facies reconstruction. Sedimentology 50, 187-210. https://doi.org/10. 1046/j.1365-3091.2003.00545.x.

Bosman, C., Uken, R., Ovechkina, M.N., 2007. The Aliwal Shoal revisited: new age constraints from nannofossil assemblages. South African Journal of Geology 110,

647-653. https://doi.org/10.2113/gssajg.110.4.647.

Brooke, B.P., Nichol, S.L., Huang, Z., Beaman, R.J., 2017. Palaeoshorelines on the Australian continental shelf: morphology, sea-level relationship and applications to 
environmental management and archaeology. Continental Shelf Research 134, 26-38. https://doi.org/10.1016/j.csr.2016.12.012.

Butenko, J., Milliman, J.D., Yincan, Y., 1985. Geomorphology, shallow structure, and geological hazards in the East China Sea. Cont. Shelf Res. 4, 121-141. https://doi. org/10.1016/0278-4343(85)90025-1.

Carter, R.M., Fulthorpe, C.S., Naish, T.R., 1998. Sequence concepts at seismic and outcrop scale: the distinction between physical and conceptual stratigraphic surfaces.

Sedimentary Geology 122, 165-179. https://doi.org/10.1016/s0037-0738(98) 00104-3.

Cattaneo, A., Steel, R.J., 2003. Transgressive deposits: a review of their variability. EarthScience Reviews 62, 187-228. https://doi.org/10.1016/s0012-8252(02)00134-4.

Chen, Z., Song, B., Wang, Z., Cai, Y., 2000. Late quaternary evolution of the sub-aqueous Yangtze Delta, China: sedimentation, stratigraphy, palynology, and deformation. Marine Geology 162, 423-441. https://doi.org/10.1016/s0025-3227(99)00064-x. Christie-Blick, N., Driscoll, N., 1995. Sequence stratigraphy. Annu. Rev. Earth Planet. Sci. 23, 451-478. https://doi.org/10.1146/annurev.earth.23.1.451.

Cooper, J.A.G., 1993. Sedimentation in a river dominated estuary. Sedimentology 40, 979-1017. https://doi.org/10.1111/j.1365-3091.1993.tb01372.x.

Cooper, J.A.G., Green, A.N., 2016. Geomorphology and preservation potential of coastal and submerged aeolianite: examples from KwaZulu-Natal, South Africa.

Geomorphology 271, 1-12. https://doi.org/10.1016/j.geomorph.2016.07.028.

Cooper, J., Green, A., Compton, J., 2018a. Sea-level change in southern Africa since the last Glacial Maximum. Quat. Sci. Rev. 201, 303-318. https://doi.org/10.1016/j. quascirev.2018.10.013.

Cooper, J., Green, A., Loureiro, C., 2018b. Geological constraints on mesoscale coastal barrier behaviour. Glob. Planet. Chang. 168, 15-34. https://doi.org/10.1016/j. gloplacha.2018.06.006.

Cooper, J., Green, A., Meireles, R., Klein, A., Abreu, J.D., Toldo, E., 2019. Tidal strait to embayment: seismic stratigraphy and evolution of a rock-bounded embayment in the context of Holocene sea level change. Marine Geology 415, 105972. https://doi.org/ 10.1016/j.margeo.2019.105972.

Dai, Z., Liu, J.T., Wei, W., Chen, J., 2014. Detection of the three Gorges Dam influence on the Changjiang (Yangtze River) submerged delta. Scientific Reports 4. https://doi. org/10.1038/srep06600.

Dai, Z., Fagherazzi, S., Mei, X., Gao, J., 2016. Decline in suspended sediment concentration delivered by the Changjiang (Yangtze) river into the East China Sea between 1956 and 2013. Geomorphology 268, 123-132. https://doi.org/10.1016/j. geomorph.2016.06.009.

Davis, R.A., Clifton, H.E., 1987. Sea-level change and the preservation potential of wavedominated and tide-dominated coastal sequences. Sea-Level Fluctuations and Coastal 
Evolution 167-178. https://doi.org/10.2110/pec.87.41.0167.

De Lecea, A.D., Green, A., Strachan, K., Cooper, J., Wiles, E., 2017. Stepped Holocene sealevel rise and its influence on sedimentation in a large marine embayment: Maputo Bay, Mozambique. Estuarine, Coastal and Shelf Science 193, 25-36. https://doi.org/ 10.1016/j.ecss.2017.05.015.

Di Bella, L.D., Frezza, V., Bergamin, L., Carboni, M., Falese, F., Martorelli, E., Tarragoni, C., Chiocci, F., 2014. Foraminiferal record and high-resolution seismic stratigraphy of the Late Holocene succession of the submerged Ombrone River delta (Northern Tyrrhenian Sea, Italy). Quat. Int. 328-329, 287-300. https://doi.org/10.1016/j. quaint.2013.09.043.

Dladla, N., Green, A., Cooper, J., Humphries, M., 2019. Geological inheritance and its role in the geomorphological and sedimentological evolution of bedrock-hosted incised valleys, lake St Lucia, South Africa. Estuarine, Coastal and Shelf Science 222, 154-167. https://doi.org/10.1016/j.ecss.2019.04.013.

Ericson, J., Vorosmarty, C., Dingman, S., Ward, L., Meybeck, M., 2006. Effective sea-level rise and deltas: causes of change and human dimension implications. Global and Planetary Change 50, 63-82. https://doi.org/10.1016/j.gloplacha.2005.07.004.

Fleming, B., Hay, R., 1988. Sediment distribution and dynamics on the Natal continental shelf. In: Lecture Notes on Coastal and Estuarine Studies Coastal Ocean Studies Off Natal, South Africa, pp. 47-80. https://doi.org/10.1029/In026p0047.

Flemming, B.W., 1978. Underwater sand dunes along the southeast African continental margin—observations and implications. Mar. Geol. 26, 177-198.

Flemming, B.W., Hay, R., 1984. On the bulk density of South African marine sands. S. Afr. J. Geol. 87, 233-236.

Gardner, J., Calder, B., Clarke, J.H., Mayer, L., Elston, G., Rzhanov, Y., 2007. Drowned shelf-edge deltas, barrier islands and related features along the outer continental shelf north of the head of De Soto Canyon. NE Gulf of Mexico: Geomorphology 89, 370-390. https://doi.org/10.1016/j.geomorph.2007.01.005.

Gensous, B., Tesson, M., 2003. Analysis of the postglacial deposits of the Rhône shelf (golfe du Lion). Implementation to the study of the late Quaternary depositional sequences. Bulletin de la Societe Geologique de France 174, 401-419. https://doi. org/10.2113/174.4.401.

Goodbred, S., Kuehl, S., 2000. The significance of large sediment supply, active tectonism, and eustasy on margin sequence development: Late Quaternary stratigraphy and evolution of the Ganges-Brahmaputra delta. Sedimentary Geology 133, 227-248. https://doi.org/10.1016/s0037-0738(00)00041-5.

Goodlad, S.W., 1986. Tectonic and sedimentary history of the mid-Natal valley (SW Indian Ocean): Bulletin of the Joint Geological Survey of South Africa/University of Cape Town/Marine Geoscience Unit. Council for Geoscience 15, 415.

Green, A.N., 2011. The late Cretaceous to Holocene sequence stratigraphy of a sheared 
passive upper continental margin, northern KwaZulu-Natal, South Africa. Marine Geology 289, 17-28.

Green, A., Mackay, C., 2016. Unconsolidated sediment distribution patterns in the KwaZulu-Natal Bight, South Africa: the role of wave ravinement in separating relict versus active sediment populations. African Journal of Marine Science, v. 38. https:// doi.org/10.2989/1814232x.2016.1145138.

Green, A.N., Uken, R., 2005. First observations of sealevel indicators related to glacial maxima at Sodwana Bay, northern KwaZulu-Natal: research in action. South African Journal of Science 101, 236-238.

Green, A., Ovechkina, M., Uken, R., 2008. Nannofossil age constraints for the northern KwaZulu-Natal shelf-edge wedge: implications for continental margin dynamics, South Africa, SW Indian Ocean. Continental Shelf Research 28, 2442-2449. https:// doi.org/10.1016/j.csr.2008.06.007.

Green, A.N., Dladla, N., Garlick, G.L., 2013a. Spatial and temporal variations in incised valley systems from the Durban continental shelf, KwaZulu-Natal, South Africa. Marine Geology 335, 148-161. https://doi.org/10.1016/j.margeo.2012.11.002. Green, A.N., Dladla, N.N., Garlick, L., 2013b. The evolution of incised valley systems from the Durban continental shelf, KwaZulu-Natal, South Africa. Marine Geology 335, 148-161. https://doi.org/10.1016/j.margeo.2012.11.002.

Green, A.N., Cooper, J.A.G., Leuci, R., Thackeray, Z., 2013c. Formation and preservation of an overstepped segmented lagoon complex on a high-energy continental shelf. Sedimentology 60, 1755-1768. https://doi.org/10.1111/sed.12054.

Green, A.N., Cooper, J.A.G., Salzmann, L., 2014. Geomorphic and stratigraphic signals of postglacial meltwater pulses on continental shelves. Geology 42, 151-154. https:// doi.org/10.1130/g35052.1.

Green, A.N., Cooper, J.A.G., Wiles, E.A., De Lecea, A.M., 2015. Seismic architecture, stratigraphy and evolution of a subtropical marine embayment: Maphuto Bay.

Mozambique. Mar. Geol. 369, 300-309.

Green, A.N., Cooper, J.A.G., Salzmann, L., 2018. The role of shelf morphology and antecedent setting in the preservation of palaeo-shoreline (beachrock and aeolianite) sequences: the SE African shelf. Geo-Marine Letters 38, 5-18. https://doi.org/10. 1007/s00367-017-0512-8.

Helland-Hansen, W., Gjelberg, J.G., 1994. Conceptual basis and variability in sequence stratigraphy: a different perspective. Sedimentary Geology 92, 31-52. https://doi. org/10.1016/0037-0738(94)90053-1.

Hernández-Molina, F.J., Somoza, L., Lobo, F., 2000. Seismic stratigraphy of the Gulf of Cádiz continental shelf: a model for Late Quaternary very high-resolution sequence stratigraphy and response to sea-level fall. Geological Society, London, Special Publications 172, 329-362. https://doi.org/10.1144/gsl.sp.2000.172.01.15. Hicks, N., Green, A., 2016. Sedimentology and depositional architecture of a submarine 
delta-fan complex in the Durban Basin, South Africa. Marine and Petroleum Geology 78, 390-404. https://doi.org/10.1016/j.marpetgeo.2016.09.032.

Hogg, A.G., Hua, Q., Blackwell, P.G., Niu, M., Buck, C.E., Guilderson, T.P., Heaton, T.J., Palmer, J.G., Reimer, P.J., Reimer, R.W. and Turney, C.S., 2013. SHCal13 Southern Hemisphere calibration, 0-50,000 years cal BP: Radiocarbon, v 55(4), p.1889-1903. Hwang, J.H., Van, S.P., Choi, B.J., Chang, Y.S., Kim, Y.H., 2014. The physical processes in the Yellow Sea. Ocean Coastal Management 102, 449-457. IPCC, 2019. Summary for Policymakers. In: IPCC Special Report on the Ocean and Cryosphere in a Changing Climate [H. -O. Pörtner, D.C. Roberts, V. Masson-Delmotte, P. Zhai, M. Tignor, E. Poloczanska, K. Mintenbeck, M. Nicolai, A. Okem, J. Petzold, B. Rama, N. Weyer (eds.)]. (In press).

Kendall, R.A., Mitrovica, J.X., Milne, G.A., Törnqvist, T.E., Li, Y., 2008. The sea-level fingerprint of the 8.2 ka climate event. Geology 36,423 . https://doi.org/10.1130/ g24550a.1.

Kirkpatrick, L.H., Green, A.N., 2018. Antecedent geologic control on nearshore morphological development: the wave dominated, high sediment supply shoreface of southern Namibia. Marine Geology 403, 34-47. https://doi.org/10.1016/j.margeo. 2018.05.003.

Kirkpatrick, L.H., Green, A.N., Pether, J., 2019. The seismic stratigraphy of the inner shelf of southern Namibia: the development of an unusual nearshore shelf stratigraphy. Marine Geology 408, 18-35. https://doi.org/10.1016/j.margeo.2018.11.016. Kuehl, S.A., Levy, B.M., Moore, W.S., Allison, M.A., 1997. Subaqueous delta of the Ganges-Brahmaputra river system. Mar. Geol. 144, 81-96. https://doi.org/10.1016/ s0025-3227(97)00075-3.

Lee, G.S., Yoo, D.G., Bae, S., Choul Kim, D., Yi, H.I., 2016. Seismic stratigraphy and depositional history of late Quaternary deposits in the Yellow Sea. EGU General Assembly Conference Abstracts 18.

Leonardi, N., Canestrelli, A., Sun, T., Fagherazzi, S., 2013. Effect of tides on mouth bar morphology and hydrodynamics. Journal of Geophysical Research: Oceans 118, 4169-4183. https://doi.org/10.1002/jgrc.20302.

Liu, Z.-X., Berne, S., Saito, Y., Lericolais, G., Marsset, T., 2000. Quaternary seismic stratigraphy and paleoenvironments on the continental shelf of the East China Sea. J.

Asian Earth Sci. 18, 441-452. https://doi.org/10.1016/s1367-9120(99)00077-2.

Liu, J., Milliman, J.D., Gao, S., Cheng, P., 2004. Holocene development of the Yellow Rivers subaqueous delta, North Yellow Sea. Marine Geology 209, 45-67. https://doi. org/10.1016/j.margeo.2004.06.009.

Maboya, M.L., Meadows, M.E., Reimer, P.J., Backeberg, B.C., Haberzettl, T., 2017. Late Holocene Marine Radiocarbon Reservoir Correction for the South and East Coast of South Africa.

Martin, A.K., Flemming, B.W., 1986. The Holocene shelf sediment wedge off the south 
and east coast of South Africa. Shelf Sands and Sandstones 11, 27-44.

Martin, A.K., Flemming, B.W., 1988. Physiography, structure and geological evolution of the natal continental shelf. In: Lecture Notes on Coastal and Estuarine Studies Coastal Ocean Studies off Natal, South Africa, pp. 11-46. https://doi.org/10.1007/978-1-

4757-3908-4_2.

Martínez-Carreño, N., García-Gil, S., Cartelle, V., 2017. An unusual Holocene fan-shaped subaqueous prograding body at the back of the Cíes Islands ridge (Ría de Vigo, NW Spain): geomorphology, facies and stratigraphic architecture. Marine Geology 385, 13-26. https://doi.org/10.1016/j.margeo.2016.11.015.

Mcormick, S., Cooper, J.A., Mason, T.R., 1992. Fluvial sediment yield to the natal coast: a review. Southern African Journal of Aquatic Sciences 18, 74-88. https://doi.org/10. 1080/10183469.1992.9631326.

Mellett, C.L., Plater, A.J., 2018. Drowned barriers as archives of coastal-response to sealevel rise. In: Barrier Dynamics and Response to Changing Climate, pp. 57-89.

https://doi.org/10.1007/978-3-319-68086-6_2.

Mellett, C.L., Hodgson, D.M., Lang, A., Mauz, B., Selby, I., Plater, A.J., 2012. Preservation of a drowned gravel barrier complex: a landscape evolution study from the northeastern English Channel. Marine Geology 315-318, 115-131. https://doi.org/10. 1016/j.margeo.2012.04.008.

Menier, D., Reynaud, J.-Y., Proust, J.-N., Guillocheau, F., Guennoc, P., Bonnet, S., Tessier, B., Goubert, E., 2006. Basement Control on Shaping and Infilling of Valleys Incised at the Southern Coast of Brittany. Incised Valleys in Time and Space, France, pp. 37-55. https://doi.org/10.2110/pec.06.85.0037.

Milliman, J.D., Farnsworth, K.L., 2011. River Discharge to the Coastal Ocean: A Global Synthesis: Cambridge. Cambridge University Press.

Milliman, J.D., Qin, Y.S., Park, Y., 1989. Sediment and sedimentary processes in the Yellow and East China Seas. In: Taira, A., Masuda, F. (Eds.), Sedimentary Facies in the Active Plate Margin. Terra Scientific, Tokyo, pp. 233-249.

Moes, H., Rossouw, M., 2008. Considerations for the Utilization of Wave Power around South Africa: Workshop on Ocean Energy, Centre for Renewable and Sustainable Energy Studies Abstracts, Stellenbosch, South Africa, 21 February. Nittrouer, C.A., Kuehl, S.A., Demaster, D.J., Kowsmann, R.O., 1986. The deltaic nature of Amazon shelf sedimentation. Geological Society of America Bulletin 97, 444. https:// doi.org/10.1130/0016-7606(1986)97<444:tdnoas>2.0.co;2.

Orme, A.R., 1973. Barrier and Lagoon Systems along the Zululand Coast. Los Angeles, Dept. of Geography, University of California, South Africa.

Patruno, S., Helland-Hansen, W., 2018. Clinoforms and clinoform systems: review and dynamic classification scheme for shorelines, subaqueous deltas, shelf edges and continental margins. Earth-Science Reviews 185, 202-233. https://doi.org/10.1016/ j.earscirev.2018.05.016. 
Patruno, S., Hampson, G.J., Jackson, C.A.-L., Dreyer, T., 2014. Clinoform geometry, geomorphology, facies character and stratigraphic architecture of a sand-rich subaqueous delta: Jurassic Sognefjord Formation, offshore Norway. Sedimentology 62, 350-388. https://doi.org/10.1111/sed.12153.

Patruno, S., Hampson, G.J., Jackson, C.A.-L., 2015. Quantitative characterisation of deltaic and subaqueous clinoforms. Earth Sci. Rev. 142, 79-119. https://doi.org/10. 1016/j.earscirev.2015.01.004.

Plint, A.G., Nummedal, D., 2000. The falling stage systems tract: recognition and importance in sequence stratigraphic analysis. Geological Society, London, Special Publications 172, 1-17. https://doi.org/10.1144/gsl.sp.2000.172.01.01.

Pretorius, L., Green, A., Cooper, A., 2016. Submerged shoreline preservation and ravinement during rapid postglacial sea-level rise and subsequent "slowstand". Geol. Soc.

Am. Bull. 128, 1059-1069. https://doi.org/10.1130/b31381.1.

Pretorius, L., Green, A., Cooper, J., Hahn, A., Zabel, M., 2019. Outer- to inner-shelf response to stepped sea-level rise: Insights from incised valleys and submerged shorelines.

Marine Geology 416, 105979. https://doi.org/10.1016/j.margeo.2019. 105979.

Prins, M.A., Postma, G., 2000. Effects of climate, sea level, and tectonics unraveled for last deglaciation turbidite records of the Arabian Sea. Geology 28, 375. https://doi.org/ 10.1130/0091-7613(2000)28<375:eocsla>2.0.co;2.

Rampino, M.R., Sanders, J.E., 1980. Holocene transgression in south-Central Long Island, New York. Sedimentary Petrology 50, 1063-1080.

Ramsay, P.J., Cooper, J.A.G., 2002. Late Quaternary Sea-Level Change in South Africa. Quat. Res. 57, 82-90. https://doi.org/10.1006/qres.2001.2290.

Ramsey, C.B., 2001. Development of the radiocarbon calibration program. Radiocarbon 43, 355-363. https://doi.org/10.1017/s0033822200038212.

Reimer, P.J., Bard, E., Bayliss, A., Beck, J.W., Blackwell, P.G., Ramsey, C.B., Buck, C.E., Cheng, H., Edwards, R.L., Friedrich, M., Grootes, P.M., Guilderson, T.P., Haflidason, H., Hajdas, I., et al., 2013. IntCal13 and marine13 radiocarbon age calibration curves 0-50,000 years cal BP. Radiocarbon 55, 1869-1887. https://doi.org/10.2458/azu_js_ rc.55.16947.

Rodriguez, A.B., Simms, A.R., Anderson, J.B., 2010. Bay-head deltas across the northern Gulf of Mexico back step in response to the 8.2ka cooling event. Quaternary Science Reviews 29, 3983-3993. https://doi.org/10.1016/j.quascirev.2010.10.004.

Salzmann, L., Green, A., Cooper, J.A.G., 2013. Submerged barrier shoreline sequences on a high energy, steep and narrow shelf. Mar. Geol. 346, 366-374. https://doi.org/10. 1016/j.margeo.2013.10.003.

SAN (South African Navy), 2014. Tide tables. South African Navy, Simonstown. Sanders, J.E., Kumar, N., 1975. Evidence of shoreface retreat and in-place "drowning" during Holocene submergence of barriers, Shelf off Fire Island, New York. Geological Society of America Bulletin 86, 65. https://doi.org/10.1130/0016-7606(1975) 
86<65:eosrai 2 2.0.co;2.

Schumann, E.H., 1988. Physical Oceanography off Natal: Lecture Notes on Coastal and Estuarine Studies Coastal Ocean Studies Off Natal, South Africa. pp. 101-130. https://doi.org/10.1029/ln026p0101.

Shepard, F.P., 1963. Submarine Geology: New York. Harper and Row (557 p). Shtienberg, G., Dix, J., Waldmann, N., Makovsky, Y., Golan, A., Sivan, D., 2016. LatePleistocene evolution of the continental shelf of Central Israel, a case study from Hadera. Geomorphology 261, 200-211. https://doi.org/10.1016/j.geomorph.2016. 03.008 .

Smith, A.M., Mather, A.A., Bundy, S.C., Cooper, J.A.G., Guastella, L.A., Ramsay, P.J., Theron, A., 2010. Contrasting styles of swell-driven coastal erosion: examples from KwaZulu-Natal, South Africa. Geological Magazine 147, 940-953. https://doi.org/ 10.1017/s0016756810000361.

Stanley, D.J., Warne, A.G., 1994. Worldwide initiation of Holocene marine deltas by deceleration of sea-level rise. Science 265, 228-231. https://doi.org/10.1126/ science.265.5169.228.

Syvitski, J.P., Saito, Y., 2007. Morphodynamics of deltas under the influence of humans. Glob. Planet. Chang. 57, 261-282. https://doi.org/10.1016/j.gloplacha.2006.12. 001.

Syvitski, J.P.M., Kettner, A.J., Overeem, I., Hutton, E.W.H., Hannon, M.T., Brakenridge, G.R., Day, J., Vörösmarty, C., Saito, Y., Giosan, L., Nicholls, R.J., 2009. Sinking deltas due to human activities. Nat. Geosci. 2, 681-686. https://doi.org/10.1038/ngeo629.

Ta, T., Nguyen, V., Tateishi, M., Kobayashi, I., Tanabe, S., Saito, Y., 2002. Holocene delta evolution and sediment discharge of the Mekong River, southern Vietnam. Quat. Sci.

Rev. 21, 1807-1819. https://doi.org/10.1016/s0277-3791(02)00007-0.

Törnqvist, T.E., Bick, S.J., González, J.L., Borg, K.V.D., Jong, A.F.M.D., 2004. Tracking the sea-level signature of the 8.2 ka cooling event: new constraints from the Mississippi Delta. Geophysical Research Letters 31. https://doi.org/10.1029/ 2004 gl021429.

Vörösmarty, C.J., Syvitski, J., Day, J., Sherbinin, A.D., Giosan, L., Paola, C., 2009. Battling to save the world's river deltas. Bull. At. Sci. 65, 31-43. https://doi.org/10.2968/ 065002005.

Wang, H., Wu, X., Bi, N., Li, S., Yuan, P., Wang, A., Syvitski, J.P., Saito, Y., Yang, Z., Liu, S., Nittrouer, J., 2017. Impacts of the dam-orientated water-sediment regulation scheme on the lower reaches and delta of the Yellow River (Huanghe): A review. Global and Planetary Change 157, 93-113. https://doi.org/10.1016/j.gloplacha. 2017.08.005.

Wei, W., Dai, Z., Mei, X., Liu, J.P., Gao, S., Li, S., 2017. Shoal morphodynamics of the Changjiang (Yangtze) estuary: Influences from river damming, estuarine hydraulic engineering and reclamation projects. Marine Geology 386, 32-43. https://doi.org/ 
10.1016/j.margeo.2017.02.013.

Yang, S., Milliman, J., Li, P., Xu, K., 2011. 50,000 dams later: erosion of the Yangtze River and its delta. Global and Planetary Change 75, 14-20. https://doi.org/10.1016/j.

gloplacha.2010.09.006.

Zecchin, M., Catuneanu, O., 2013. High-resolution sequence stratigraphy of clastic shelves I: units and bounding surfaces. Marine and Petroleum Geology 39, 1-25. https://doi.org/10.1016/j.marpetgeo.2012.08.015.

Zecchin, M., Civile, D., Caffau, M., Sturiale, G., Roda, C., 2010. Sequence stratigraphy in the context of rapid regional uplift and high-amplitude glacio-eustatic changes: the Pleistocene Cutro Terrace (Calabria, southern Italy). Sedimentology 58, 442-477. https://doi.org/10.1111/j.1365-3091.2010.01171.x.

Zecchin, M., Gordini, E., Ramella, R., 2015. Recognition of a drowned delta in the northern Adriatic Sea, Italy: stratigraphic characteristics and its significance in the frame of the early Holocene sea-level 


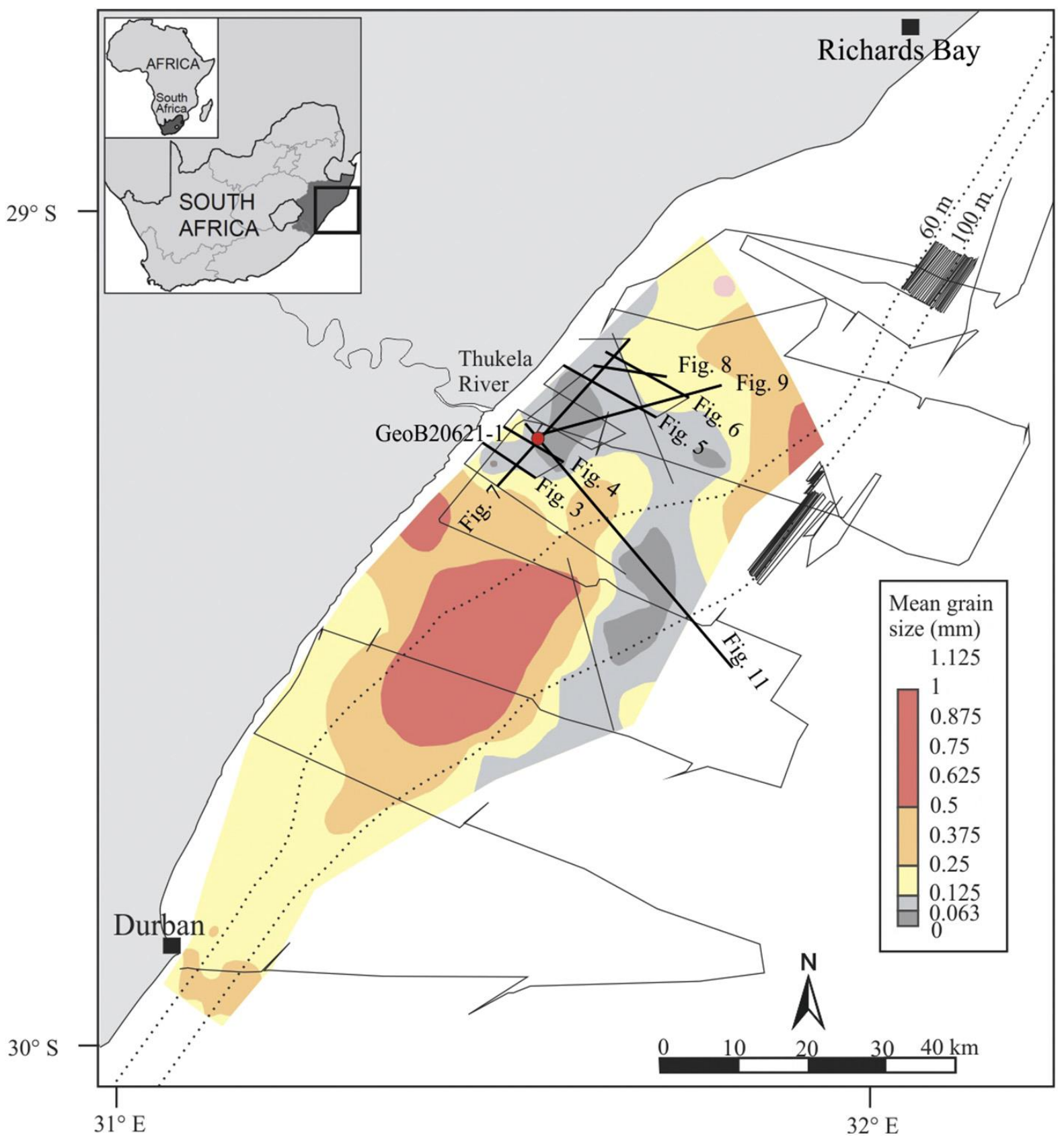

Fig. 1. Locality map, overlain with mean grain size distribution (modified from Green and Mackay, 2016), illustrating the extent of the seismic coverage and core locality. 


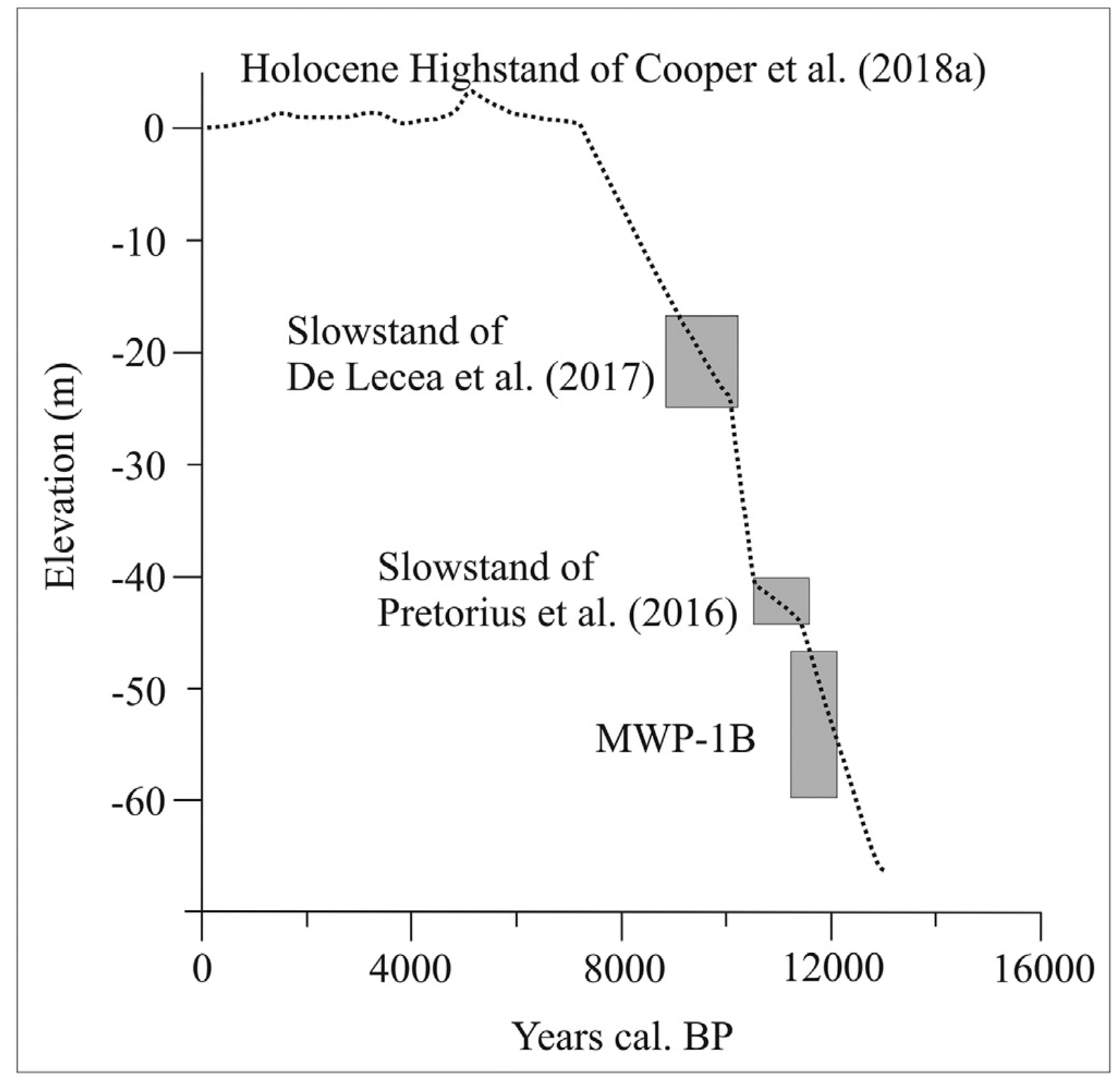

Fig. 2. Relative sea level curve from the east coast of southern Africa (after Cooper et al., 2018a). 

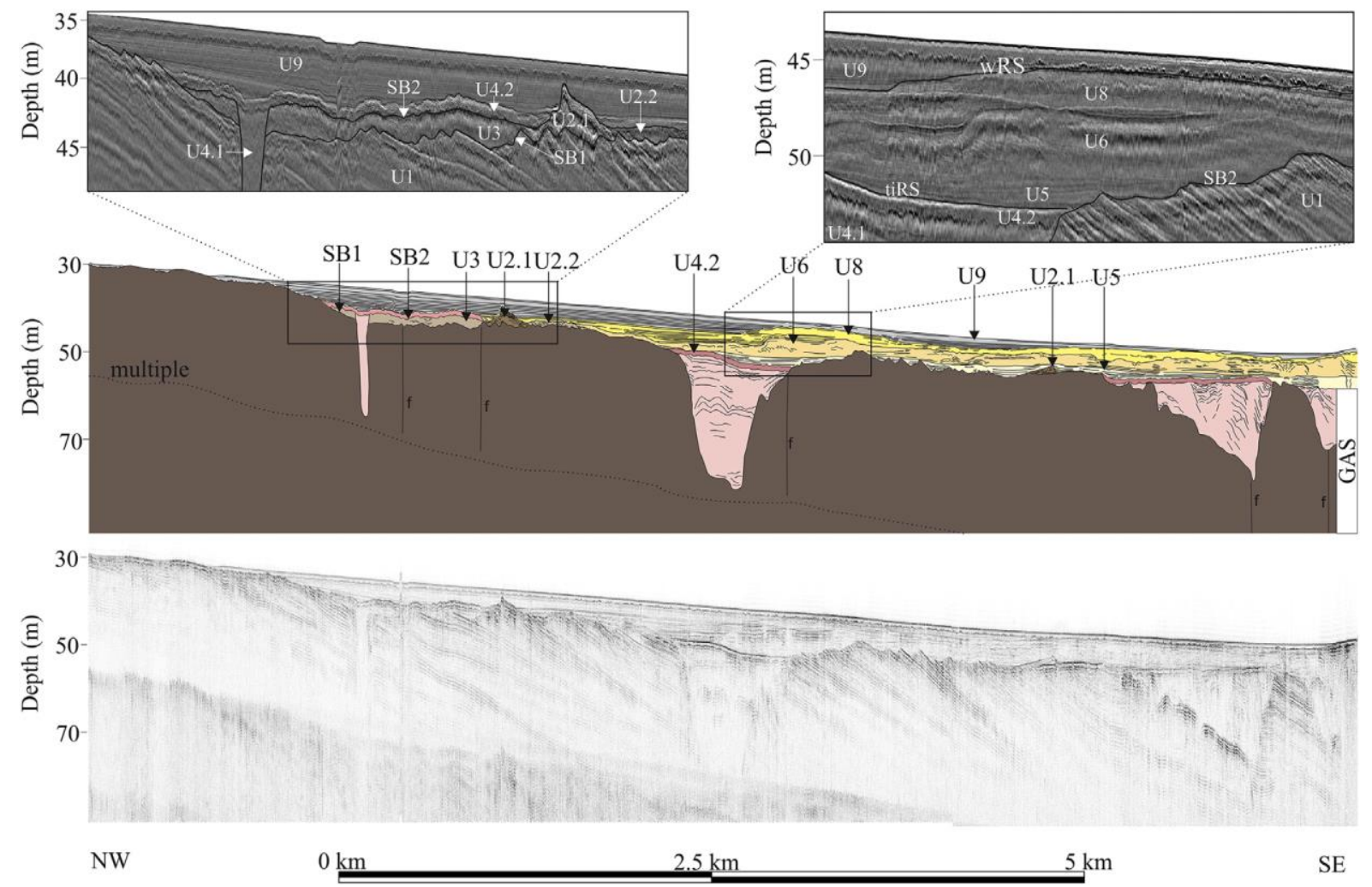

Fig. 3. West to east orientated, coast-perpendicular boomer seismic profile. Note the fault-controlled position of SB2 incisions, as well as the variable widths and depths of each incision. Left inset displays Unit 3 landward of pinnacle Unit 2.1, with Unit 2.2 observed seaward. Right inset reveals flat lying unit 5 overlain by concave down reflectors of Unit 6. 

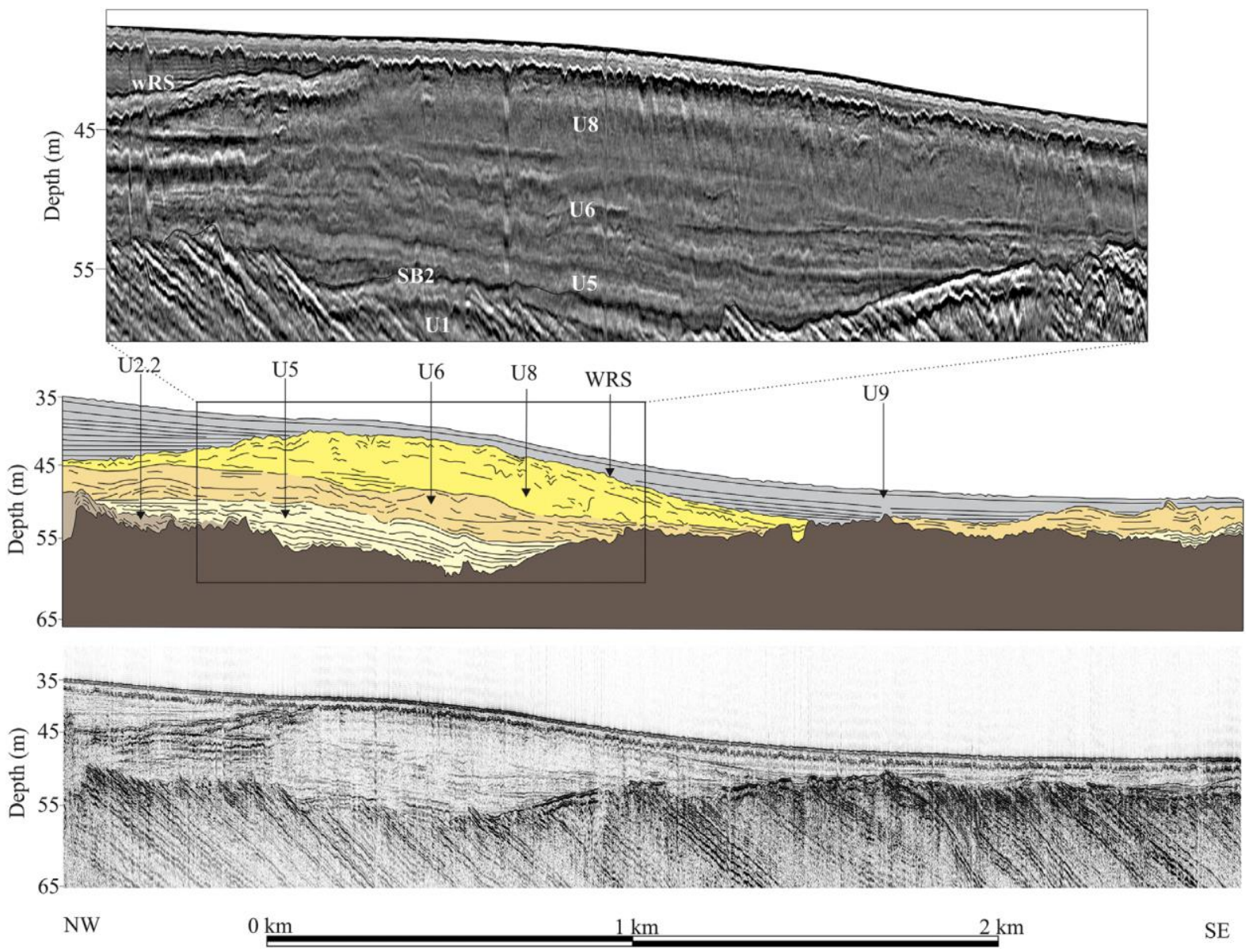

Fig. 4. West to east orientated, coast-perpendicular boomer seismic profile. Note the mounded geometries of units 6 and 8 , creating localised relief in the seafloor 


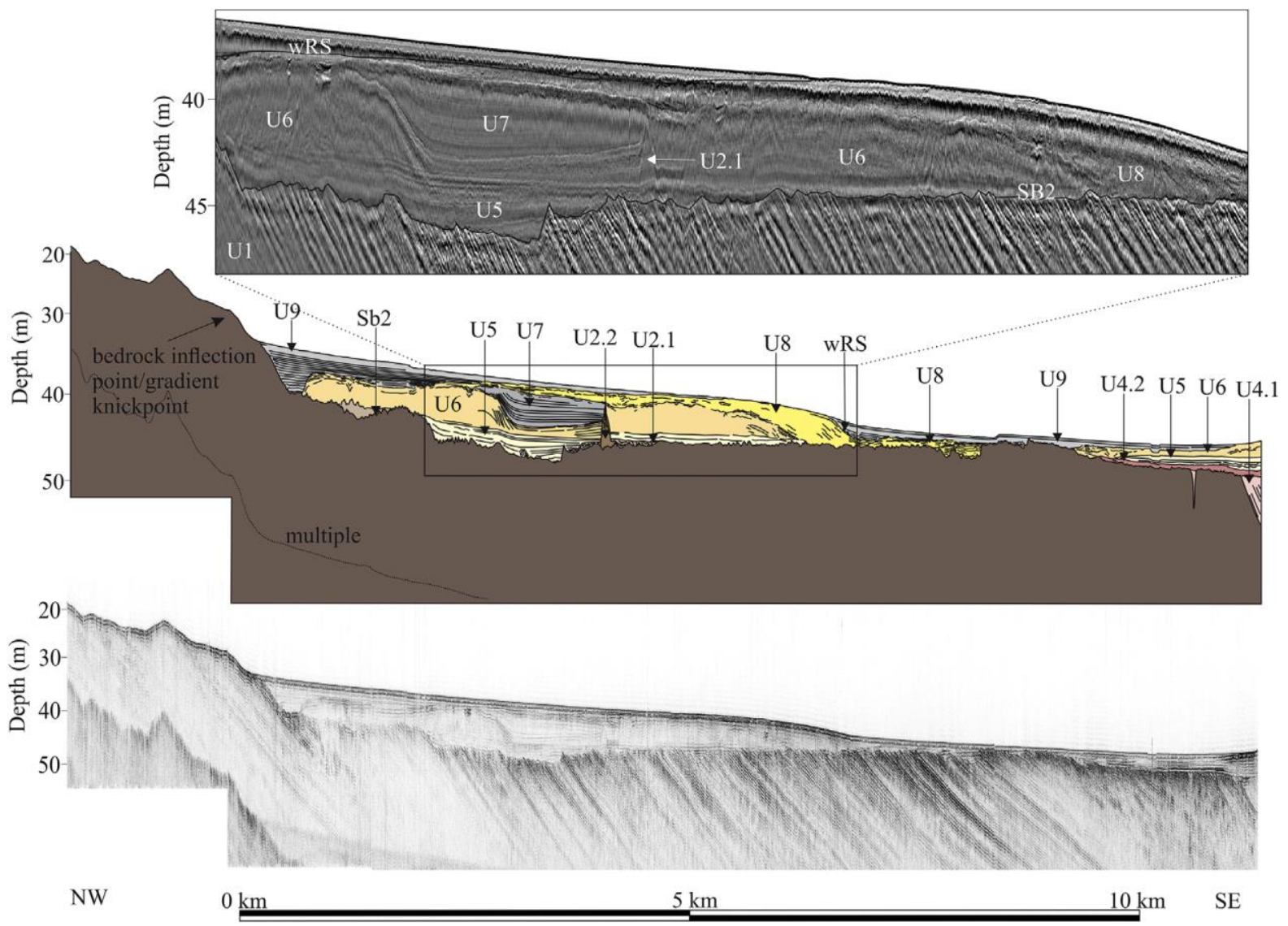

Fig. 5. West to east orientated, coast-perpendicular boomer seismic profile. Note the bedrock highs in the landward section, with deposition mostly occurring seaward of the bedrock inflection point/gradient knickpoint. 

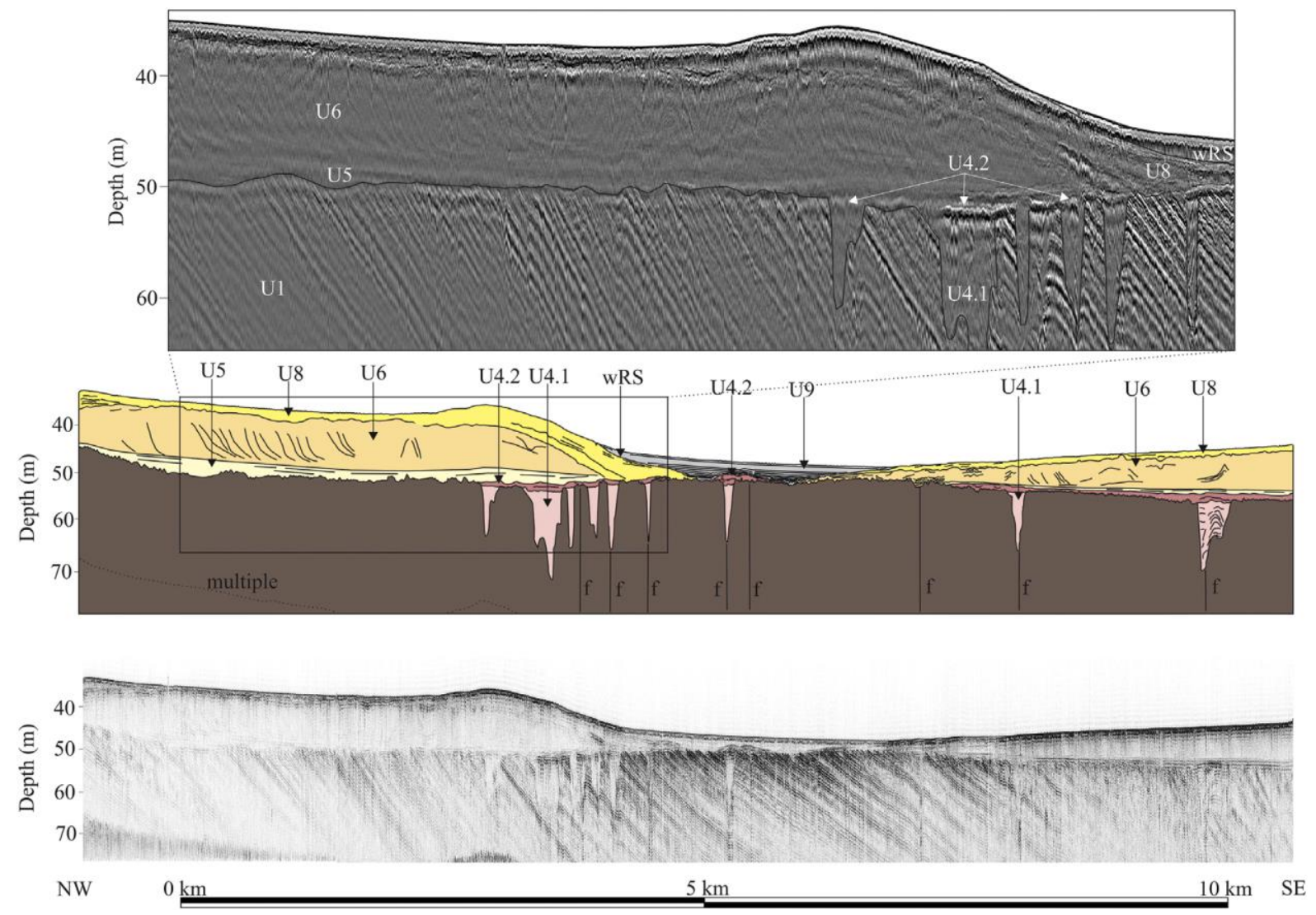

Fig. 6. West to east orientated, coast-perpendicular seismic profile. Note the fault-controlled position of SB2 incisions, as well as positive seafloor relief controlled by units 6 and 8.
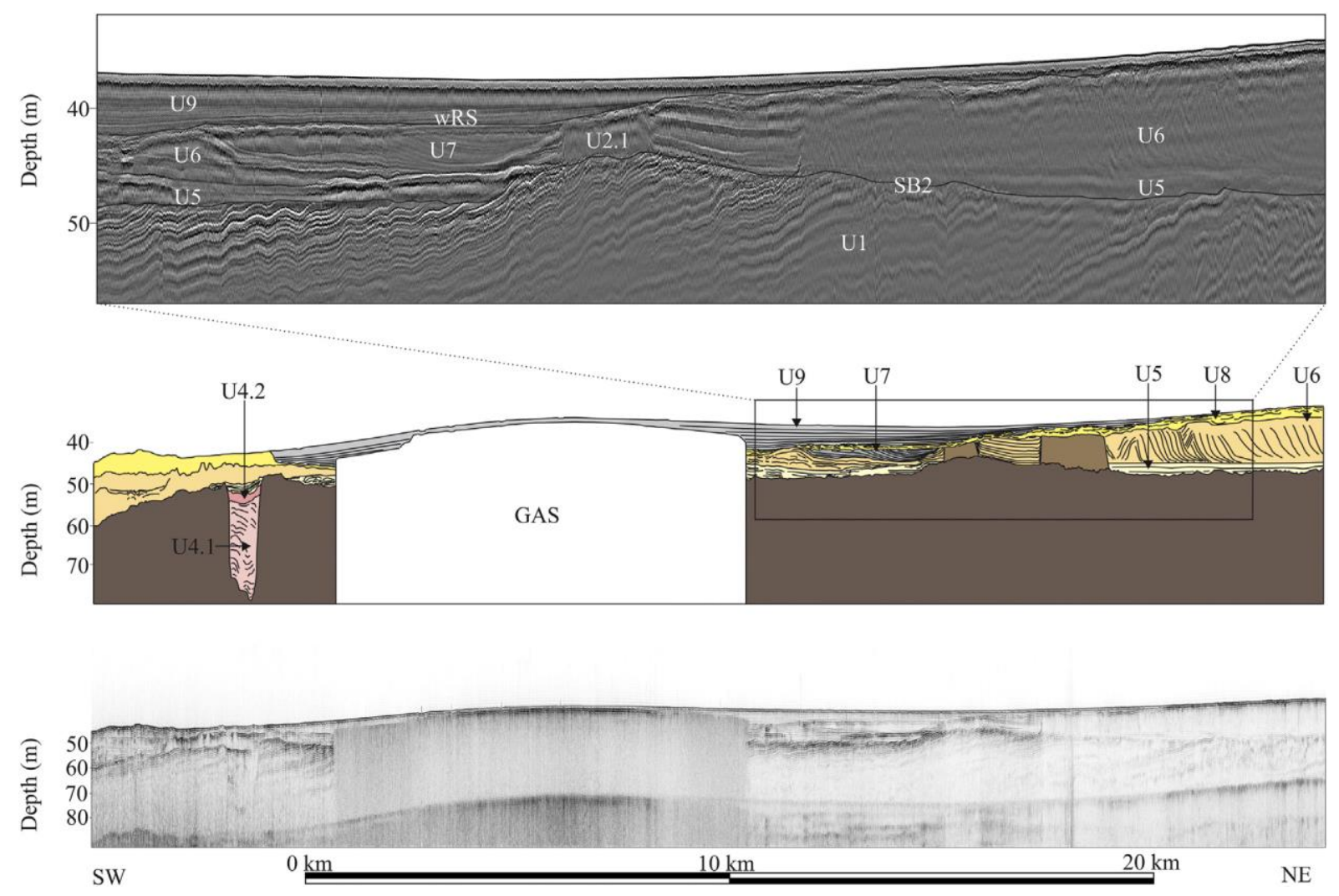
Fig. 7. Coast-parallel boomer seismic section. Note Unit 6's bimodal progradation direction alongshelf
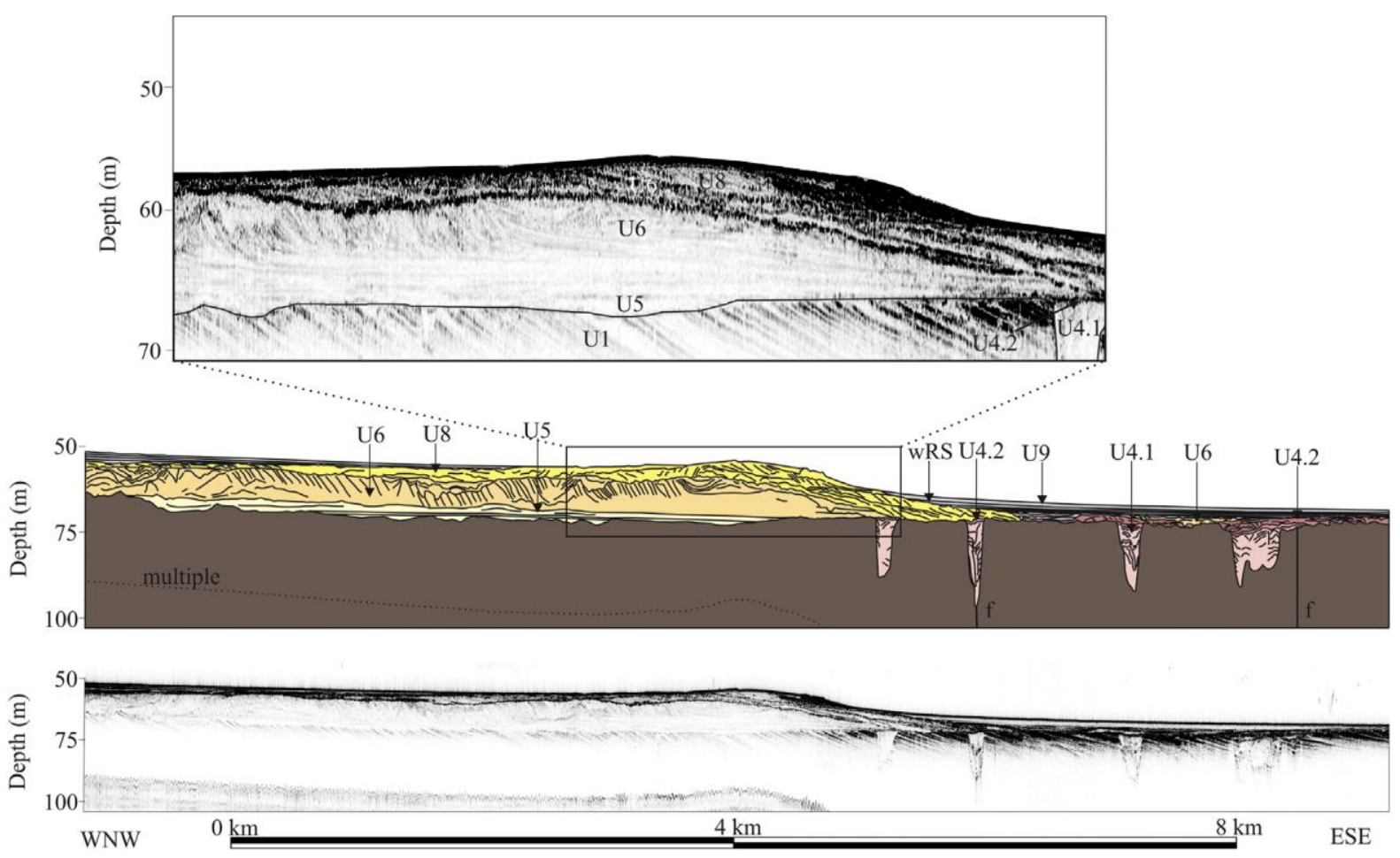

Fig. 8. West to east orientated, coast-perpendicular PARASOUND seismic profile. Note the relationship between the location of units 6 and 8 , and matching positive relief in the seafloor, underlain by a flat-lying and thin Unit 5 .
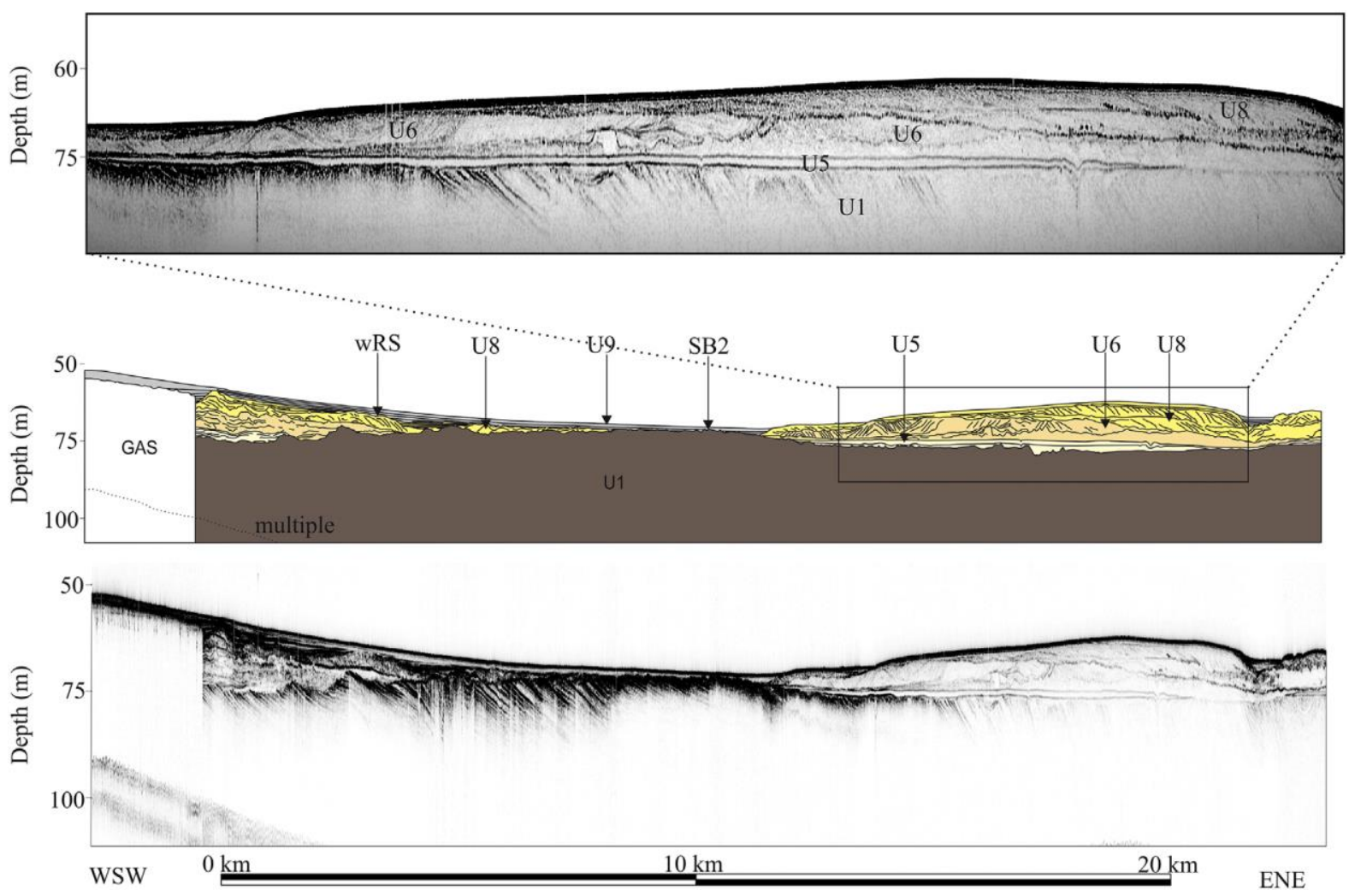
Fig. 9. Coast parallel PARASOUND seismic profile. Note the bimodal dip directions of the reflectors within units 6 and 8.

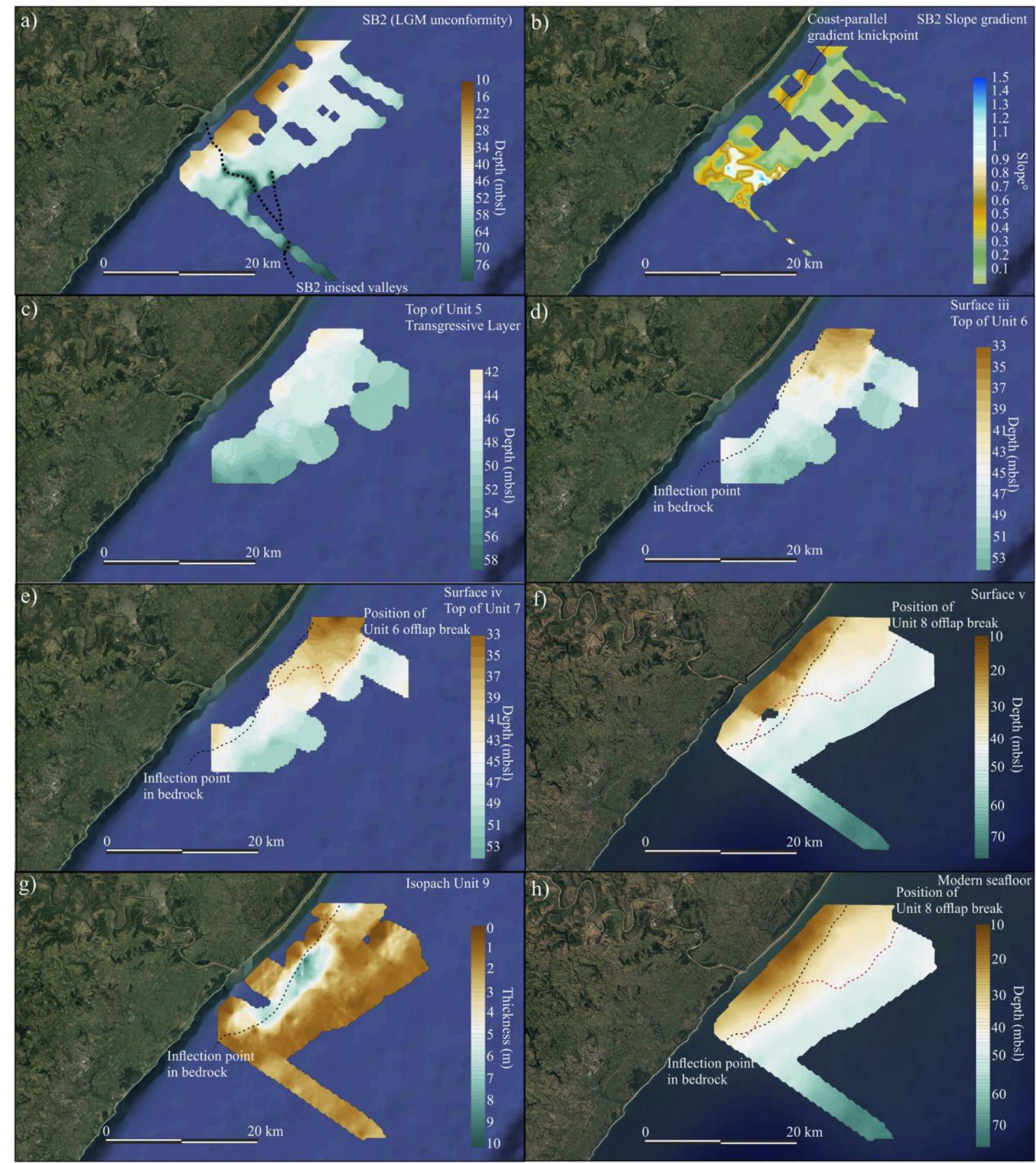

Fig. 10. Depth structure surface plots of the main stratigraphic surfaces. a) SB2 unconformity displaying offshore continuation of the modern day drainage pattern. b) Slope gradient of SB2 unconformity. Note the increase in slope gradient with incision depth. c) Distribution of the flat featureless transgressive surface, marking the top of Unit 5. d) Top of unit 6 (denoted by surface III), with topset break forming an arcuate shape that widens northwards. e) Top of Unit 7 (denoted by surface IV).

Note the lobate shape of the underlying unit 6. f) Top of Unit 8 (denoted by surface V), the upper bounding surface of delta phase 2 . Note the landward position of the 
lobe relative to the inflection point of the bedrock. g) Isopach map of Unit 9. Note the location of the mud depocentre, seaward of the bedrock knickpoint. h) Modern

seafloor bathymetry. Note areas of positive relief in the seafloor that match the locations of units 6 and 8.
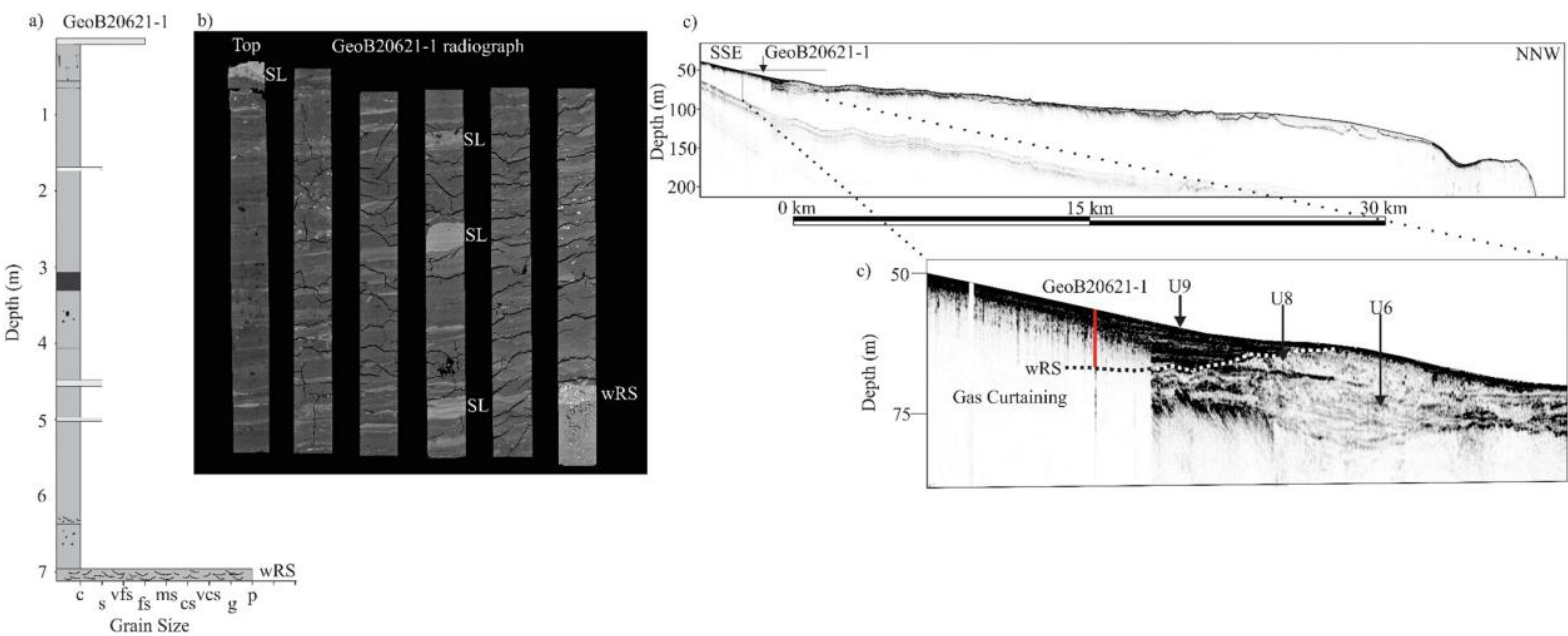

Fig. 11. a) Core GeoB20621-1, b) Core radiograph. $S L$ = sand layer. Note the coarse basal constituents of the core. c) West to east orientated, coast-perpendicular

PARASOUND profile depicting location of core. Enlarged seismic data details muddy and gassy layer in the acoustic profile, together with extrapolated wRS and core position. 


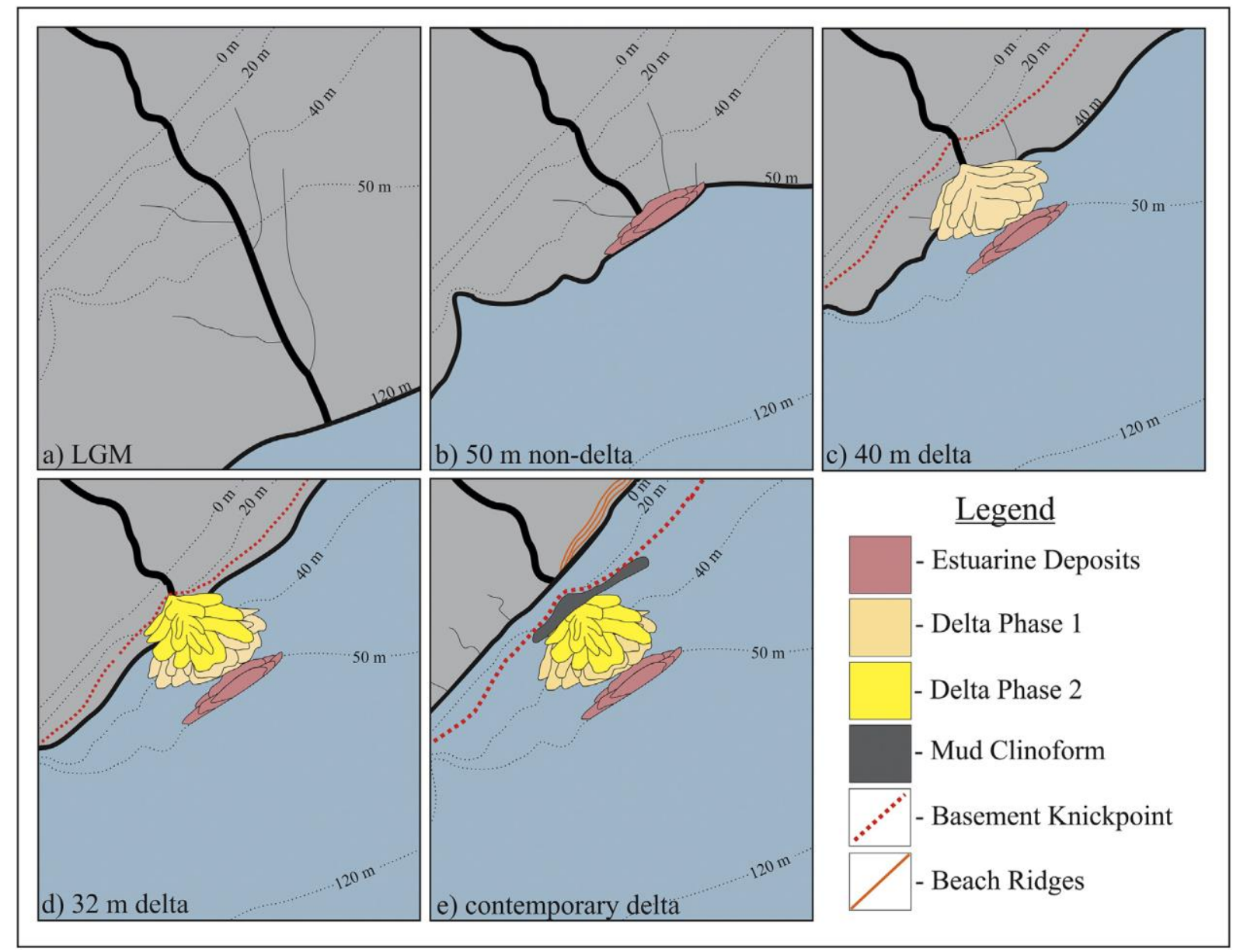

Fig. 12. Schematic evolutionary summary of the Thukela shelf stratigraphy. a) Maximum fluvial incision into the basement strata occurred during the LGM, with valley positioning closely related to faulting. b) Estuarine deposition occurred during sea level occupation of $50 \mathrm{~m}$, as underfilled valley accommodation precluded deltaic construction. c) Construction of delta phase 1 occurred during sea level stillstand/slowstand at $40 \mathrm{~m}$, with antecedent basement high points constraining its landward position. d) Backstepping and construction of delta phase 2 at sea level occupation at $32 \mathrm{~m}$, with basement morphology again constraining its landward position. e) Contemporary delta deposition seaward of the basement highs, as a ubiquitous mud deposit and an onshore beach ridge plain. 